\title{
Educational Game Development Models
}

\section{Mehmet Emin Korkusuz* \& Ayşen Karamete}

\author{
Balıkesir University, Balıkesir, TURKEY
}

Received: 07.05.2013

Accepted: 11.09.2013

\begin{abstract}
Recent research on the subject shows that students spend more time on computer games than other activities such as reading book or watching TV. It is possible that this time-consuming activity can become much more effective by educator-game sector cooperation. Which type of game students prefer mostly; how the educational content can be articulated the games without diminishing the playability and enjoyableness of it; and the impact of the competition in the games on process and students are just several titles examined in the studies. This scope presents the types of computer game, qualities of educational games, and educational games designs which are recommended for developing educational games. It also presents a set of knowledge about the importance of educational games in mathematics and physic education, and some studies on this field. In the scope, some strategies, about educational game development process, are recommended educators and software developers in the sector who intend to develop educational games based on the literature.
\end{abstract}

Key words: educational .computer game, game design, educational game development model

DOI No: http://dx.doi.org/10.12973/nefmed203

\section{Summary}

Introduction: As an entertainment means computer games become more interesting increasingly and more preferable than other media, such as cinema or TV, for people in every ages. Even players spend much time for computer games. When considered age distribution, it's understood that the young is predominate among players. In this situation, using computer games in education is a nonignorable alternative when considered the opportunities it presents.

Computer games can be examined under the different types from various points of view. One of the widely accepted game-grouping studies is presented by Prensky (2001). According to this grouping study, computer games are examined under the eight titles as action games,

\footnotetext{
${ }^{*}$ Corresponding author: Dr.Mehmet Emin Korkusuz, Department of Computer Education and Instructional Technology, Necatibey School of Education, Balıkesir University,10100 Balıkesir, TURKEY.

E-mail: ekorkusuz@gmail.com
} 
adventure games, fight games, puzzle games, make-believe games, simulation games, sport games and strategy games.

Any game has some distinctive qualifications. Prensky states that games occur by combining twelve features. While he identifies six of them as features rendering games funnier he says the others as basic structural features. These are rules, targets and aims, outcomes and feedbacks, conflict/contest/defiance/competition/interaction and story. With technological advancements, traditional games begin to give their places to computer games. This fact paves the way for using computer games in education. Both present games can be used educational manner and games designed specifically for educational aims can be used.

Various educational game development models are presented so that a computer game can be prepared with min labour or cost and max benefit. In this study, those game development models are to be presented: EFM (Effective Learning Environment), FIDGE (Fuzzified Instructional Design Development of Game-like Environments), GOM (Game Object Model), (DGBL - Digital Game Based Learning), GAM (Game Achievement Model), EGM (Experiential Gaming Model) and Spiral Educational Game Design.

It is observed that students develop negative attitude against science and mathematics lessons. Thus, that students having negative attitude against any lesson would fail in it is inevitable. The computer games in which students are naturally interested might be effective means to change student's attitudes against these lessons and to increase their success.

Methodology: In this study, the literature on "educational game design" and "computer games" were reviewed and the obtained results were examined. As a result of this, in this study it is presented the basic components on which educational game models are based and development processes, recommended by them.

Conclusion and Suggestions: Educational game development process is long, complicated and expensive. Because of the rapid advancements many projects become outmoded as they are just in build phase, so some of them might be cancelled before accomplishing. Thus, there is need some suggestions about the process by which designers might discard errors taking so long time, and returns might be minimized. That most studies presenting in this scope have not been tested practically is a very big deficiency. To present educational game development studies, based on design models suggested, and effects of the results on the process might be fill a gap in the scope. 


\title{
Eğitsel Oyun Geliştirme Modelleri
}

\section{Mehmet Emin KORKUSUZ ${ }^{\dagger}$, Ayşen KARAMETE}

\author{
Balıkesir Üniversitesi, Balıkesir, TÜRKİYE
}

Makale Gönderme Tarihi: 07.05.2013

Makale Kabul Tarihi: 11.09.2013

Özet - Son yıllarda yapılan çeşitli araştırmalar, öğrencilerin hayatlarında bilgisayar oyunlarına, televizyon, kitap okumak gibi diğer faaliyetlerden daha fazla yer verdiklerini göstermektedir. Öğrencilerin oldukça fazla zamanını alan bu etkinliğin, eğitimci ve oyun sektörünün iş birliğiyle daha verimli hale dönüştürülmesi mümkün görülmektedir. Öğrencilerin hangi oyun türlerini daha çok tercih ettikleri, oyundan zevk almalarını sağlayan unsurların neler olduğunun belirlenmesi, eğitsel içeriğin oyunun oynanabilirliğinin ve eğlencesinin azaltılmadan oyunlara eklenebilmesi, oyunlardaki rekabetin sürece ve öğrencileri etkisi araştırma alanlarından sadece bir kısmıdır. Bu çalışmada bilgisayar oyunu türleri, eğitsel oyunların özellikleri ve eğitsel oyun geliştirebilmek için önerilen eğitsel oyun tasarım modelleri yer almaktadır. Fen ve matematik alanlarında öğrencilerin ders başarılarının, motivasyon ve tutumlarının düşük olması ve kavram yanılgılarının fazla olması nedeniyle, özellikle bu alanda geliştirilecek eğitsel oyunların öneminden bahsedilmiştir. Çalışmada, literatür temelinde eğitsel oyun geliştirmek isteyen eğitimcilere ve sektördeki yazılım geliştiricilere, eğitsel oyun geliştirme sürecine yönelik stratejiler önerilmiştir.

Anahtar Kelimeler: eğitimsel bilgisayar oyunları, oyun dizaynı, eğitsel oyun geliştirme modeli

\section{Giriş}

Bir eğlence aracı olarak bilgisayar oyunları her yaştan insanın ilgisini çekmekte ve sinema, televizyon gibi ortamlara göre daha fazla tercih edilir hale gelmektedir. Üstelik bilgisayar oyuncuları bu faaliyetlere oldukça fazla zaman ayırmaktadırlar. Örneğin "World of Warcraft" oyununu oynayanların, oyunu oynamak için haftada ortalama 22,7 saatlik bir zaman dilimini ayırdıkları görülmüştür (Konuksal, Bölüm Sonu Canavarı, 2009). "Call of Duty Black Ops" isimli oyunu oynayanların ise oyunun çıkışını takip eden ilk bir ay içerisinde oyunda geçirdikleri toplam süre 600 milyon saati aşmıştır (Süngü, 2010).

Bilgisayar oyuncularının yaş dağılımına bakıldığında, gençlerin büyük bir çoğunluk oluşturduğu görülmektedir. GfK'nın araştırmasına göre bilgisayar oyunu oynayan her 10 kişiden 63,24'dü 24 yaşın altındadır (Gfk, 2009). Araştırmalarda da görüldüğü gibi

\footnotetext{
† İletişim: Mehmet Emin Korkusuz, Yrd. Doç. Dr., Bilgisayar ve Öğretim Teknolojileri Eğitimi Bölümü, Necatibey Eğitim Fak., Balıkesir Üniversitesi, 10100, Balıkesir, TÜRKIYY.

E-mail: ekorkusuz@gmail.com
} 
öğrencilerin hayatında bilgisayarlar ve bilgisayar oyunları önemli bir yer tutmaktadır. Geçmişte sokakta saklambaç gibi oyunlar oynayan öğrenciler artık, telefonlarda, tabletlerde ve dizüstü ve masaüstü bilgisayarlarda bilgisayar oyunları oynamaya başlamışlardır.

\section{Bilgisayar oyunlarl}

Bilgisayar oyunlarının gelişimi, bilgisayarların gelişimi ve yaygınlaşması ile paralel olmuştur. Bilgisayarların işlem güçleri ve grafik yetenekleri arttıkça oyunların özellikleri gelişmiş, bilgisayarlar yaygınlaştıkça da oyun oynayanlar ve dolayısıyla da oyunlarla ilgilenen firmaların sayısı artmış, bunun sonucu olarak da çok çeşitli ve kaliteli oyunlar ortaya çıkmıştır.

Bilgisayar oyunları farklı yaşlarda, farklı cinsiyetlerde ve farklı kültürlerdeki oyuncular için çok çeşitli türlerde geliştirilmektedir. Örneğin, futbol veya basketbol gibi sporlardan hoşlanan oyuncular için spor oyunları üretilirken, kız çocukları için bebek giydirme, makyaj yapma gibi küçük çaplı oyunlar üretilmektedir (Wikipedia, Bilgisayar Oyunu, 2011).

Bilgisayar oyun türleri farklı kaynaklarda farklı şekillerde tanımlanmıştır (Crawford, 1982). Prensky bilgisayar oyunlarını; aksiyon oyunları, macera oyunları, dövüş oyunları, bulmaca oyunları, rol yapma oyunları, simülasyon oyunları, spor oyunları ve strateji oyunları olarak aşağıda kısaca açıklanan sekiz başlık altında toplamıştır (Prensky, 2001):

Aksiyon Oyunları: Oyunların en temel ve en geniş türüdür. Aksiyon filmlerinin oyunlardaki karşılığı olarak düşünülebilir. Bu tür oyunlarda, oyuncu sürekli olarak oyuna anlık müdahaleler yapar ve aktif olarak oyunun içindedir. Savaş ve şiddet öğeleri yer alabilir. Birinci şahıs nişancı (FPS), araba yarışı gibi oyunlar bu türe ait oyunlardır.

Macera Oyunları: Oyuncu bilinmeyen sanal bir dünyanın içindedir. Araştırarak, keşfederek, bu dünyada nesneler toplayarak çeşitli problemleri çözer. Oyunun akışı genellikle hikâye odaklıdır. Zork ve Resident Evil serileri, macera oyunlarının önemli örneklerindendir.

Dövüş Oyunları: Oyuncu, kendi seçtiği karakter ile bilgisayar ya da diğer oyuncu tarafından kontrol edilen diğer karakterler ile dövüşür. Klasik bir örneği Street Fighter oyunudur.

Bulmaca Oyunları: Oyuncuların labirent gibi bir ortamda dolaştığı ya da mantıksal problemler çözdüğü oyunlardır. Tetris türevleri bu tip oyunlara örnek gösterilebilir.

Rol Yapma Oyunları (RPG): Oyuncunun insan ya da herhangi bir canlı karakteri yönettiği oyunlardır. Oyuncu oyunda mücadele ettikçe deneyim ve çeşitli ekipmanlar kazanarak karakterini geliştirir. Diablo, Fall Out oyunları RPG türüne örnektir. 
Çevrim içi olarak ve çok kullanıcı ile oynanan RPG oyunlarına MMORPG (Massive Multiplayer Online Role Playing Game - Devasa Çok Kullanıcılı Rol Yapma Oyunları) denilmektedir.

Simülasyon Oyunları: Gerçek hayatta olan bir durumun oyunsallaştırılarak bilgisayar ortamına aktarılmış halleridir. Örneğin, bir şehir kurabilir, bir uçak kullanabilir ya da bir şirketin yöneticisi olabilirsiniz. Örnek olarak Electronic Arts firmasının SimCity serisi, Microsoft'un Flight Simulator serisi verilebilir.

Spor Oyunları: Fiziksel sporların bilgisayar ortamında olanlarıdır. Oyunlarda, bazen oyuncu olunurken bazen teknik direktör olunabilir. Futbol, basketbol gibi tek spor dalını içeren oyunlar olabildiği gibi olimpiyat sporları, kış sporları gibi başlıklar altında pek çok sporun yer aldığ 1 paketler de bulunabilmektedir. FIFA Soccer, Fight Night Round, Winter Games spor oyunlarına örnek olarak verilebilir.

Strateji Oyunları: Oyuncunun ordu, halk gibi büyük grupları yönettiği oyunlardır. Gerçek zamanlı (Real-Time Strategy - RTS) ve Sıra Tabanlı (Turn-Based Strategy - TBS) olmak üzere iki ana türe ayrılmaktadır. Gerçek zamanlı strateji oyunlarında oyuncu rakipleriyle karşılıklı hamleler yoluyla mücadele eder. Sıra tabanlı strateji oyunları ise, satranç gibi, hamlelerin sırayla yapıldığı oyunlardır. The Battle for Wesnoth TBS'ye, Age Of Empires ise RTS'ye örnek olarak verilebilir.

Prensky’nin taksonomisi dışında kalan ancak diğer araştırmacılarca bahsedilen oyun türleri ise şunlardır (Graser, 2009):

Müzik Oyunları: Belirli ritim, nota ya da hareket dizgelerini tekrar etmek üzerine kurulu oyunlardır. Genellikle gitar, dans pad gibi yardımcı bir araç kullanılır. Guitar Hero, Rock Band ve Sing Star oldukça popüler olmuş müzik oyunlarındandır.

Parti Oyunları: Oyuncuların birlikte oynayabilmesi için özellikle çok oyunculu olarak geliştirilmiş küçük oyunlardır. Fiziki olarak bir araya gelen oyuncular, içlerinden kimin en iyi, en hızlı olduğunu belirlemeye çalışırlar. Mario Party serisi, Crash Boom Bang! ve Rayman Raving Rabbids, türün önde gelen oyunlarındandır.

Bilgisayar oyunlarının türleri zaman içinde kullanıcı tercihlerine göre değişiklik gösterebilmektedir. Oyun firmaları geliştirdikleri oyunları daha fazla ilgi görmesi için farklı oyun türlerinden özellikler taşıyacak şekilde geliştirmektedir. 


\section{Oyunların Özellikleri}

Bilgisayar ve bilgisayar oyunları insanlık tarihinin en ilgi çekici eğlencesi olma potansiyeline sahiptir. Ancak her eğlenceli etkinlik oyun olarak nitelendirilemez. Maroney, amaçları ve yapısı olan eğlenceyi oyun olarak tanımlamıştır (Maroney, 2001). Kramer, oyunun yapısını donanım, kurallarını ise yazılıma benzeterek yazılım ve donanımın bir araya gelerek oyunu oluşturduğunu söylemiştir (Kramer, 2000). Prensky ise daha kapsamlı bir tanım yapmış ve oyunların, on iki unsurun bir araya gelerek oluştuğunu söylemiştir. Bu on iki unsur şunlardır (Prensky, 2001):

1. Oyunlar eğlendiricidir ve zevk verir.

2. Oyunlar sürükleyicidir ve tutkuyla bağlanmayı sağlar.

3. Oyunların kuralları vardır. Kurallar oyunun yapısını oluşturur.

4. Oyunların motive edici amaçları vardır.

5. Oyunlar etkileşimlidir ve oyuncunun aktif katılımını sağlar.

6. Oyunların zorluğu oyuncunun başarısına göre ayarlanabilir. $\mathrm{Bu}$ durum, oyuncuları oyunda tutar.

7. Oyunların çıktıları ve dönütleri vardır. Oyuncular bu sonuçlar sayesinde öğrenirler.

8. Oyunlarda oyuncunun galip gelerek egosunu tatmin edebileceği durumlar vardir.

9. Oyunlarda mücadele, yarış, meydan okuma ve rekabet vardır. Bu durum oyunculara heyecan verir.

10. Oyunlarda çözülmesi gereken problemler vardır. Bu, oyuncuların yaratıcılığını geliştirir.

11. Oyunlarda oyuncular arası etkileşim vardır. Sosyal gruplar oluşmasını sağlar.

12. Oyunların sundukları hikâyeler vardır. Oyuncular hikâyenin bir parçası olarak hikâyedeki duyguları yaşarlar.

Prensky, on iki özellikten altı tanesini, oyunları eğlenceli kılan özellikler olarak tanımlarken diğer altısını temel yapısal özellikler olarak tanımlamaktadır. Bir oyunda mutlaka bulunması gereken altı temel unsur şunlardır (Prensky, 2001):

Kurallar: Oyunların diğer eğlence türlerinden farkı çeşitli kurallarının bulunmasıdır. Düzenlenmiş kuralları olmayan bir eğlenceyi, oyun olarak tarif etmek mümkün değildir. Kurallar oyunları tüm oyuncular için adil ve heyecan verici yapmalıdır. 
Oyunda kaç oyuncunun olacağı, oyuncuların rolleri, geribildirimler, oyun düzeyleri arasındaki geçişler, oyuncunun davranışlarına göre oyun içerisinde ilerlemenin ne şekilde gerçekleşeceği, oyunun zorluk düzeyi, bunların oyuncuya sunulması ve hikâye ile bağdaştırılması gibi konular oyun kuralları ile belirlenir (Kramer, 2000; Prensky, 2001; Maroney, 2001).

Özetle kurallar; oyunu yapılandırır, oyunun amaçlarının fark edilmesini sağlar, oyuncunun hareketlerini sınırlandırır, oyuncuyu strateji geliştirmeye zorlar (Kula, 2005).

Hedefler ve Amaçlar: Amacı olan bir oyunda hedefe ulaşmak motivasyonu büyük miktarda arttırır. Oyunlarda hedefler "yüksek skor elde etmek", "bayrak kazanmak", "sona ulaşmak" gibi olabilmektedir ve bu hedefler oyunun kurallarıyla doğrudan ilişkilidir. Hedefe ulaşmak bazen sıkıcı olsa veya oyuncuları zorlasa da oyuncunun kapasitesini ortaya çıkarmak üzere ona baskı kurduğu ve kazanmaya ittiği için oldukça önemlidir.

Çıktılar ve Geribildirimler: Hedefe ne kadar ulaşıldığının ölçülmesi, kazanma ya da kaybetme bildirimlerinin verilmesi bakımından geribildirimler oyuncular için önemlidir. Bildirimler çok çeşitli formlarda olabilir ama temel özellikleri "anında" dönüt vermeleridir.

Geribildirimler, oyuncuya oyun anında yaptıkları aktivitelerin başarıya ulaştıran aktivite olup olmadığıyla ilgili anında bilgi verdikleri için oyuncunun stratejisini gözden geçirmesini, gerekiyorsa farklı bir strateji denemesini sağlayarak oyun içinde öğrenmeyi kolaylaştırırlar.

Çatışma/yarışma/meydan okuma/rekabet: İnsan olma doğası gereği, rekabet bulunduran ortamlarda birey, rakiplerinin önüne geçerek en başarılı olma eğilimindedir. $\mathrm{Bu}$ durum, oyuncuya kendi karakteriyle özdeşleşerek oyunda da başarılı olma isteği kazandırır. Genel oyunlar bir problem çözme etkinliği olarak düşünüldüğünde, oyuncunun o problemi çözmek için bazen bilgisayara karşı bazen de diğer oyunculara karşı mücadele etmesi, meydan okuması, rakipleriyle çatışması gerekir.

Etkileşim: Etkileşimin, geribildirimler yoluyla oyun ve oyuncu arasındaki etkileşim ve oyuncunun diğer oyuncularla sosyal ortamdaki etkileşimi olmak üzere iki boyutu vardır. Bilgisayara karşı oynanan oyunların bazılarında da yapay zekâ algoritmaları sayesinde, bilgisayarın insana daha yakın düşünerek seçimler yapmasının sağlanabilmesi, gün geçtikçe daha iyi durumlara gelmektedir.

Hikâye: Bir oyunun ne hakkında olduğuyla ilgilidir. Örneğin, satranç rekabet, tetris doku inşa etme, The Age of Empires savaş stratejisiyle ilgilidir. Oyunun hikâyesinin oyuncuya çoğunlukla oyunun başında bildirilmesi gerekmektedir. Bu bildirim genellikle 
oyunun hedefleriyle beraber sunulur. Hedefleri çok açık olan satranç gibi oyunlarda hikâyeyi sunmaya gerek olmayabilir.

Oyunun güçlü ve etkili bir hikâyesinin olması, oyuncunun, oynadığg karakteri daha çok benimseyip oyunun hedeflerini gerçekleştirme isteğini arttırmada önemli bir yere sahiptir.

\section{Ĕgitsel Bilgisayar Oyunlarl}

Bilgisayar oyunlarının, oyuncuların motivasyonu üzerinde olumlu etkilere sahip olduğu kabul edilmektedir (Malone, 1981; Alessi \& Trollip, 2001; Garris, Ahlers \& Driskell, 2002). $\mathrm{Bu}$ motivasyonun temel kaynağı olan eğlence sayesinde, oyuncular kendileri için gerekli olabilecek bilgileri oyun oynama sırasında kazanabilirler (Pillay, 2002). Crawford (1984)'a göre oyun oynamanın eğitimsel bir değeri vardır. Eğitimsel değerin yanında tamamen eğitim amacıyla geliştirilmiş oyunlar da vardır. Bu tür oyunlar eğitsel oyunlar olarak ifade edilmektedir ve bu tür oyunlar üzerinde yapılan çalışmalar nispeten yeni olmakla birlikte giderek çoğalmaktadır (Üçgül, 2006).

Young (2004), eğitsel oyunların sınıf içinde önemli bir yer tutabilmesi için üç konuda değişiklik yapılması gerektiğini belirtmiştir:

1. Yapılandırmacı kurama uygun olarak test performansına dayanmayan, çok geniş kapsamlı bir müfredat yerine hedeflerin daha açık sunulduğu, anlamlı öğrenmeye yönelik bir yapı hazırlanmalıdır.

2. Psikomotor becerilere yönelik oyunlar yerine, sosyal ve bilişsel becerileri ön plana çıkarak MMORPG oyunlar geliştirilmelidir.

3. Proaktif öğretim tasarımları geliştirmek için oyunların öğrenme kuramı açısından anlaşılması gerekir.

Demirel, Seferoğlu ve Yağcı (2003)'ya göre eğitsel oyunlar, “Oyun formatını kullanarak öğrencilerin ders konularını öğrenmesini sağlayan ya da problem çözme yeteneklerini geliştiren yazılımlardır." Oyunlar problem çözmenin özellikleri olan problemin yapılandırılması, alternatif çözümler geliştirilmesi, bilinmeyen sonuca ulaşılması gibi özelliklerin yanında şans, yarış, rekabet gibi özellikler de içerir (Bottino, Ferlino \& Travella, 2006; Ebner \& Holzinger, 2007).

Oyunlar Kirriemuir ve McFarlane'e göre (2004), karar verme, stratejik düşünme, planlama ve iletişim alanlarında çeşitli kazanımlar sağlamaktadır (Üçgül, 2006). Shaffer, Squire, Halverson ve Gee (2005) de video oyunlarının kültürel ve yeni sosyal dünyalar oluşturduğunu ve böylece düşünme, sosyal iletişim ve teknolojiyi birleştirme yoluyla 
öğrenmeye yardımcı olduğunu söylemektedir. Bunun yanında Gee (2003) ve Whelan (2005), bilgisayar ve video oyunlarının, iyi tasarlandığı takdirde asıl önemini, eğlence ve öğrenmenin eş zamanlı olarak oyunların içindeki sanal dünyalarda insanların kendilerini yeniden yaratmasıyla meydana geldiğini söylemektedir (Bakar, Tüzün \& Çağıltay, 2008).

Eğitsel bilgisayar oyunları üzerine araştırmalar yapan Linderoth, Lantz-Andersson ve Lindström (2002), oyunların okullardaki ders konularını öğretmek üzere üç farklı biçimde kullanıldığını belirtmiştir: Simülasyonlar şeklinde gerçek hayatın elektronik ortamda canlandırılması, öğrenciler için bir motivasyon kaynağı olarak derse güdülenmenin sağlanması ve konuların sunumu için bir araç olarak kullanılması.

Eğitsel bilgisayar oyunlarının bir diğer avantajı da çok kolay öğrenilebilmeleridir. Siang ve Rao (2003)'e göre bilgisayar oyunları tüm bilgisayar programları arasında en kısa öğrenme eğrisine sahip olan programlardır. Ayrıca oyuncular, yardım dosyaları okumak ya da yönergeleri takip etmek yerine, doğrudan oyunu oynayarak, yaşayarak öğrenirler.

Günümüzde geliştirilmiş birçok eğitsel oyun ve bu oyunlar üzerine yapılmış birçok araştırma mevcuttur. Öğrencileri hedef alan ilk eğitsel bilgisayar oyunu 1971 yılında MECC araştırma merkezi tarafından Oregon Trail ismiyle üretilmiştir.

1973 yılında eğitsel bilgisayar oyunlarının matematik eğitimi amacıyla kullanıldığı Plato isimli bir proje geliştirilmiştir. Bu proje kapsamında geliştirilen bilgisayar oyunu öğrenciler üzerinde denenmiştir. Sonuç olarak matematik başarısında ve matematiğe yönelik öğrenci tutumlarında olumlu etkiler gözlenmiştir.

Yıllar geçtikçe bilgisayar oyunlarının eğitimde kullanımı ve bunun sonucu olarak öğrencilerin eğitsel bilgisayar oyunlarına olan ilgileri giderek artmıştır. 1982 yılında lise öğrencilerinin dijital mantık devreleri tasarlayabilmeleri için geliştirilmiş Rocky Boots isimli oyun 100.000 adet satılmıştır.

İlerleyen yıllarda eğitsel oyun sektöründe gerileme yaşanmış, oyun firmaları küçük bütçelerle kalitesiz, yeniliklerden uzak oyunlar geliştirmişlerdir. $\mathrm{Bu}$ dönemde eğitsel oyunların yerini, Sim City, Lemmings, Civilization gibi eğlence amaçlı oyunların eğitsel amaçlı kullanımı almıştır (Egenfeldt-Nielsen, 2005).

Prensky (2001)'nin aktardığına göre, William Stock, 400 farklı okulda araştırma yaparak eğitsel bilgisayar oyunu kullanan deney grubu öğrencilerinin kontrol grubu öğrencilerine göre standart testlerde \%30 daha başarılı olduğunu bulmuştur. William Stock’a 
göre bu başarının en büyük sebebi, deney grubu öğrencilerinin ders dışı zamanlarda da eğitsel bilgisayar oyunlarını oynayarak öğrenme süresini arttırmış olmalarıdır.

Etkileşimli oyun tabanlı öğrenme aracı geliştiren Mann ve diğerleri (2002), cerrahi yönetim algoritmasının öğretimi konusunda çalışma yapmışlardır. Çalışma sonrasında, öğrencilerin test puanlarında artış gözlenmiş ve öğrencilerin ortamı eğlenceli buldukları sonucuna ulaşılmıştır.

Bartholomew ve diğerleri (2006), geliştirdikleri bilgisayar oyununu astım hastası öğrencilere hastalıkla mücadele etmeyi öğretmek için kullanmıştır. Araştırma sonucunda, oyun oynayan astım hastası öğrencilerin hastaneye kaldırılma sayılarında azalma olduğu, daha az sayıda hastalık belirtisine rastlandığı ve bu öğrencilerin günlük faaliyetlerini daha rahat yapabildikleri ifade edilmiştir.

Bilgisayar oyunları ile stratejik ve mantıksal düşünme beceresinin ilişkisinin araştırıldığı çalışmada Bottino ve diğerleri (2006), oyunların öğrencilerin stratejik ve mantıksal düşünme becerileri üzerinde olumlu etkisinin olduğunu belirlemişlerdir.

Brom, Preuss ve Klement (2011), Çek Cumhuriyeti'nde gerçekleştirdikleri araştırmada 4 farklı liseden 5 sınıf ile çalışmıştır. Çalışmada normal eğitimin ardından ek olarak oyun ile eğitim gerçekleştirilmiştir. Oyunun amacı öğrenilenleri pekiştirmek ve birleştirmektir. Öncelikle her sınıf rastgele ikiye ayrılmıştır. Deney grubu Orbis Pictus Bestialis isimli oyunu oynarken kontrol grubu çoklu-ortam öğeleri barındıran ek bir ders almıştır. Çalışma sonunda; oyun oynayarak öğrenmenin geleneksel öğretimle karşılaştırıldığında pozitif etkilerinin olduğu, oyun oynamanın zararlı olmadığı ancak öğretimi ek olarak güçlendirmediği ve oyun grubunun başarısının iyi olduğu ancak kontrol grubuna göre az miktarda düşük olduğu ve oyun oynayarak öğrenmenin öğrencilerin ilgisini çektiği belirlenmiştir.

Garris, Ahlers ve Driskell (2002)'in aktardığına göre, McDonald (1993) ve Ricci (1996) yaptıkları araştırma sonucunda eğitsel özellikleri olan bilgisayar oyunlarının öğrenmeyi iyileştirdiğini göstermişlerdir. McDonald (1993)'a göre eğitsel bilgisayar oyunları öğrencilerin daha fazla risk almalarına, risk alan öğrencilerin oyundaki görevlerinde daha 1srarlı davranmalarına sebep olmaktadır ve dolayısıyla öğrencilerin öğrenme performansları daha fazla gelişmektedir. Ayrıca, Ricci (1996)'ye göre eğitsel bilgisayar oyunları öğrencileri motive etmektedir. Motive olan öğrenciler eğitim verilen konuya daha fazla odaklanmakta ve öğrenme performansları artmaktadır.

Günümüzde oyun sektörünün büyümesi, geniş bant internetin yaygınlaşması ve bilgisayar teknolojisinin ilerlemesiyle birlikte eğitsel oyunlar da gelişmiştir. Artık eğitsel 
oyunlar birçok öğrencinin sosyal bir yapının parçası olarak birlikte eğlenmelerine ve öğrenmelerine imkân tanımaktadır.

Bilgisayar oyunları sanal ortamlarla gerçek yaşam arasında bir köprü kurarak, bireylerin eleştirel düşünceye sahip olmasını sağlamaktadır (Turvey, 2006). Öğrenciler oyunun kurallarını, oyun ortamında deneyerek ve aldıkları geribildirimlerle öğrenmektedirler (Funk, 2003).

Ural'a göre, özellikle formal eğitim dönemindeki bireylerin bilgisayar oyunları ile bu derece yoğun ilgilenmeleri bilgisayar oyunlarından eğitimde faydalanmanın önemini arttırmaktadır. Öğrencilerin bu derece isteyerek katıldıkları bir aktivitenin aynı zamanda onların bilişsel, duyuşsal, psikomotor gelişimlerini desteklemesi de sağlanırsa bilgisayar oyunları eğitimciler için bulunmaz bir fırsat niteliği taşıyabilecektir (Ünal, 2009).

Günümüzde bilgisayar oyunları derste ana materyal olarak kullanılması tercih edilse de ilk başlarda sadece, dikkat ve motivasyonunu yükselten birer araç olarak kullanılmıştır. Oyun oynama ve eğitsel amaçlar arasındaki denge dikkatli ve etkin bir şekilde kurulmalıdır. (Kiili, 2005a). Bu durum göz önüne alınarak, bilgisayar oyunlarının tasarım aşamasında, oyundaki seviyelerin daha dikkatli tasarlanması gerekmektedir (Pelletier, 2005).

Eğitsel bilgisayar oyunu geliştirebilmek için, oyuncuların oyun ortamında çevreyle nasıl etkileşime geçtikleri, geri bildirimleri nasıl değerlendirdikleri ve nasıl öğrendiklerinin anlaşılabilmesi oldukça önemlidir (Ang \& Rao, 2008).

Garris, Ahlers ve Driskell (2002), oyun yoluyla öğrenmenin nasıl olacağına dair bir model ortaya koymuştur. Bu çalışmada önerilen oyun tabanlı öğrenme modeli Şekil 1'deki gibidir.

Girdi

Süreç Oyun Döngüsü

Çıktı

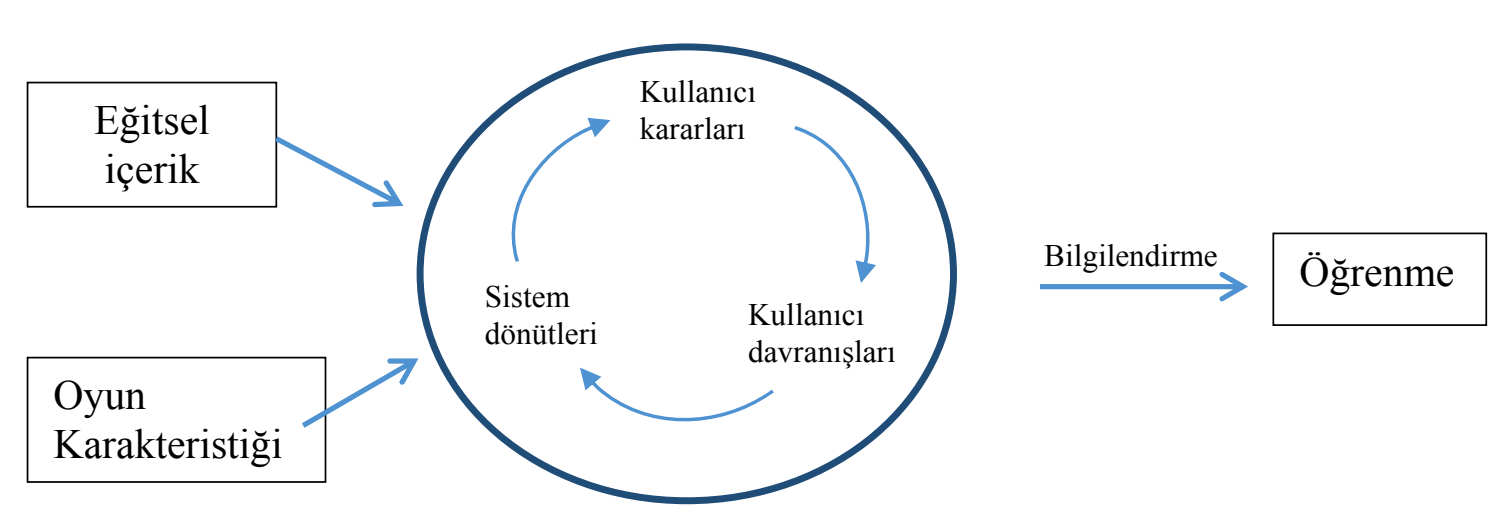

Şekil 1 Girdi-Süreç-Çıktı Oyun Modeli (Garris, Ahlers \& Driskel , 2002). 
Garris'in oyun tabanlı öğrenme modeline göre, oyun başladığında oyun döngüsü de başlar. Oyun döngüsüne oyun karakteristiği ve öğretim içeriği birlikte dâhil olur. Oyuncu oyun döngüsü içinde oyunun yapısını keşfeder ve öğretimsel içerikle karşılaşır. Oyun tamamlandığında bilgi alınmış ve öğretim gerçekleşmiştir (Garris, Ahlers \& Driskell, 2002).

Eğitsel bir bilgisayar oyunu geliştirilirken oyun tabanlı öğrenmenin nasıl gerçekleştiği bilgisi 1şığında, eğitsel yazılım geliştirme basamaklarını izlemek faydalı olacaktır. Ancak eğitsel bir oyun geliştirirken eğitsel öğeler ile oyunu bir araya getirmek karmaşık bir işlemdir (Güneş, 2010). Oyun geliştirilmeden önce eğitsel bir oyunun yapısının nasıl olması gerektiği bilinmelidir. Eğitsel oyunların yapısı ile ilgili olarak literatürde çeşitli çalışmalar bulunmaktadır. İpek (2001), eğitsel bir oyunun yapısının Şekil 2'deki gibi olması gerektiğini belirtmiştir.

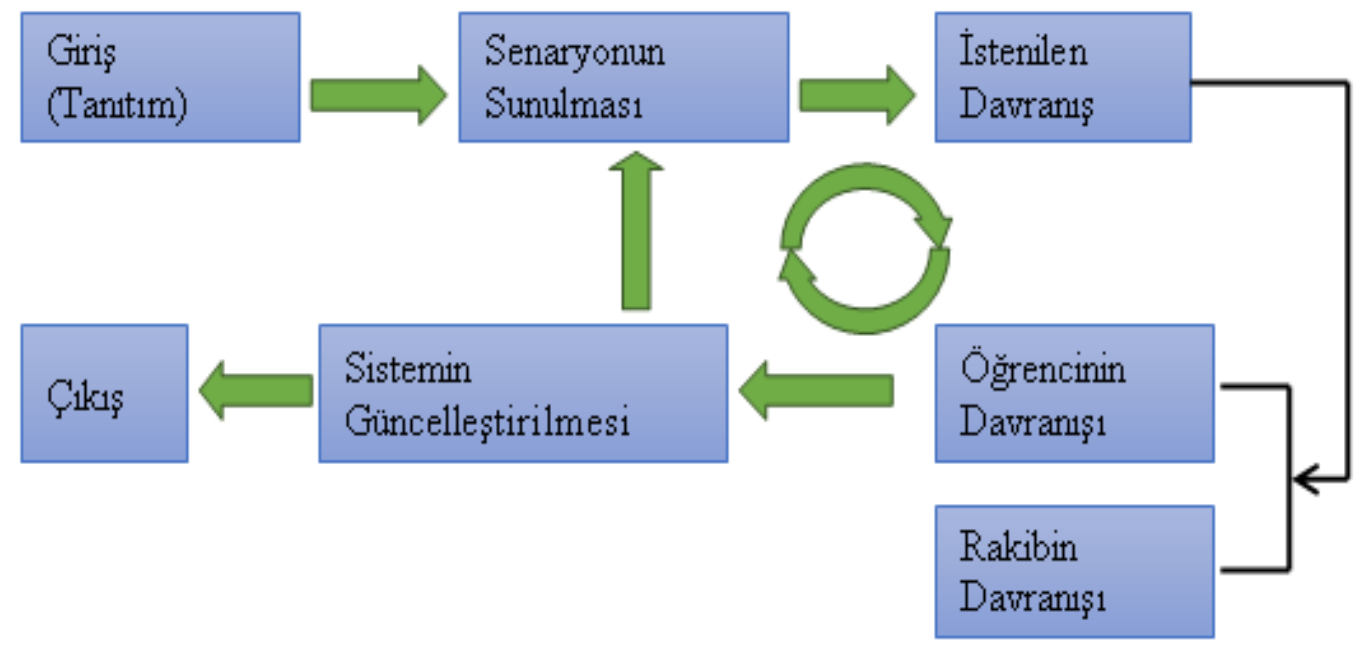

Şekil 2 Eğitsel Oyun Yazılımlarının Genel Yapısı (İpek, 2001).

$\mathrm{Bu}$ eğitsel oyun yapısında oyuncu oyuna başladığında, ilk olarak oyunun tanıtımı ile karşılaşır. Burada oyunun oynanışı hakkında genel bilgilere sahip olan oyuncu, bir sonraki adımı oluşturan senaryonun sunulması aşamasına geçerek oyunun hikâyesini ve amacını öğrenir. Oyundaki öğelerle ve rakipleriyle etkileşimde bulunarak geri bildirimler alır. Oyunun her basamağında oyuncunun yaptığı işlemler listelenerek durumu oyuncuya bildirilir.

$\mathrm{Bu}$ genel eğitsel oyun tasarım modelindeki temel yapı, farklı araştırmacılar tarafindan daha detaylı ve kapsamlı olarak literatürde incelenmiştir. Aşağıda çoğunlukla karşılaşılan oyun tasarım modellerinden bahsedilmektedir. 


\section{EFM: Eğitsel Oyun Tasarımı için Bir Model}

EFM, etkili öğrenme ortamı (Effective Learning Environment), akış deneyimi (Flow Experience) ve motivasyon (Motivation) kelimelerinin baş harfleri ile isimlendirilmiş bir modeldir. Bu tasarım modelinde adı geçen üç kuramın özellikleri birleştirilerek eğitsel oyun geliştirmek için bir yapı sunulmuştur.

EFM Modeli, temelinde bulunan motivasyonu sağlamak için ARCS Motivasyon Modelini kullanır. ARCS Motivasyon Modeli Keller tarafindan Beklenti Değer Teorisine (Expectancy-Value Theory) dayanarak geliştirilmiştir.

ARCS Motivasyon Modeli (Keller, 1984), dört ana öğrenme modeli üzerine odaklanmaktadır. Bunlar (Keller \& Suzuki, 1988; Bayram, 1999): dikkat (Attention), uygunluk (Relevance), güven (Confidence), doyum (Satisfaction) şeklindedir. Tablo 1'de ARCS Modelinin bu dört ana faktörü ve her faktörün alt basamakları listelenmiştir.

Tablo 1: ARCS Motivasyon Modeli Stratejileri.

\begin{tabular}{c|ccc}
\hline $\begin{array}{c}\text { DİKKAT } \\
\text { (Attention) }\end{array}$ & $\begin{array}{c}\text { UYGUNLUK } \\
\text { (Relevance) }\end{array}$ & $\begin{array}{c}\text { G̈̈UEN } \\
\text { (Confidence) }\end{array}$ & $\begin{array}{c}\text { DOYUM } \\
\text { (Satisfaction) }\end{array}$ \\
\hline Algısal Uyarılma & Yakınlık & Başarı Beklentisi & Doğal Sonuçlar \\
Araştırmaya Yönelik & Hedefe Yönelme & Güç Sınama & Olumlu Sonuçlar \\
Uyarılma & Güdü Uygunluğu & Destekleme & Eşitlik \\
Değişkenlik & . & \\
\hline
\end{tabular}

EFM Modeli, geliştirilen öğretim tasarımı ile ARCS Motivasyon Modeli arasındaki bağlantıyı kurabilmek için Chicago Üniversitesi'nden Csikszentrnihalyi tarafından geliştirilen Akış Deneyimi Kuramını (Flow Experience) kullanmaktadır.

Akış Deneyimi Kuramı, motivasyonu anlamak ve uygulamak için, öğretim tasarımı ve motivasyon kuramı arasında teorik bir köprü oluşturmaktadır. Bu köprü; etkinliğin hedefleri, açık geri bildirimler, mücadele-beceri dengesi, yoğunlaşma, kontrol, eylem ve farkındalık birleştirme, amacı olan deneyim, zamanın dönüşümü, bilinç kaybı adımlarından oluşmaktadır (Csikszentmihalyi, 1991).

Daha sonra Novak ve diğerleri (2000), dokuz adımı koşulların etkileri, deneyimin etkileri, sonuçların etkileri olmak üzere üç kategori altında toplamışlardır.

Etkili öğrenme ortamı tasarımı, öğrencilerin anlamalarına, ana içeriği öğrenmelerine ve kendi bilişsel yeteneklerini arttırmalarına yardımcı olmayı sağlayacak etkili ve pozitif öğrenme ortamları sağlamayı amaçlamaktadır. Bu ortamlar tasarlanırken dikkat edilmesi gereken kurallar, doğrudan katılım hissi, uygun araçlar, sürekli mücadele hissi, motivasyon, 
dikkat dağıtıcılardan kaçınma, belirli hedefler ve yerleştirilmiş işlemler, yoğun etkileşim ve geri bildirim şeklindedir.

Tüm bu basamakların birleştirildiğinde Şekil 3 ve Şekil 4'te verilen EFM'nin genel yapısı ortaya çıkar.

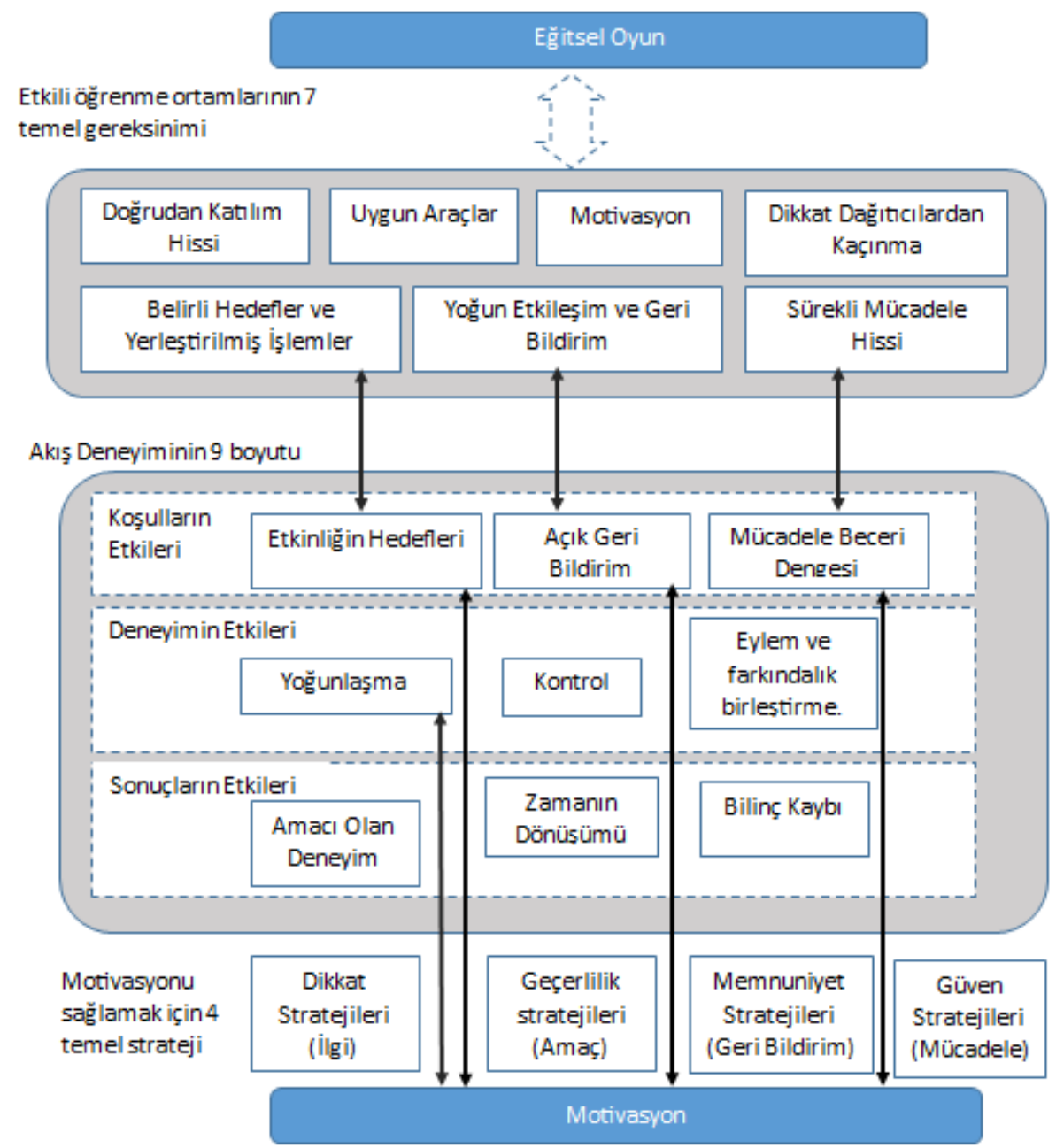

Şekil 3 Motivasyon, Akış Deneyimi, Etkili Öğrenme Ortamı Ve Eğitsel Oyun Arasındaki Bağlantı.

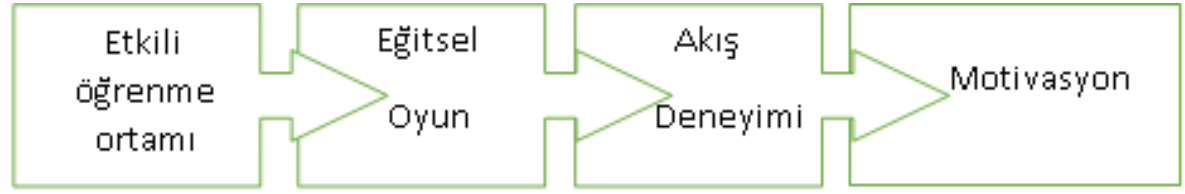

Şekil 4 Eğitsel Oyun Tasarımı İçin EFM Modeli.

Sonuç olarak EFM Modeline göre, öğrenen etkili bir öğrenme ortamında akış deneyimini yaşadığında, bu ortam öğreneni uyararak kesin olarak bir motivasyon 
sağlayacaktır. Bu açıdan bakıldığında iyi tasarlanan bir eğitsel oyun, motivasyonu sağlamak ve öğrenmeyi gerçekleştirmek için etkili bir öğrenme ortamı olmaya uygundur.

\section{FIDGE Modeli}

FIDGE, oyun benzeri ortamlar için bulanıklaştırılmış öğretim tasarımı geliştirme (Fuzzified Instructional Design Development of Game-like Environments) kelimelerinin baş harfleriyle isimlendirilmiş bir oyun tasarım modelidir.

Oyunlarla öğrenme ortamlarının nasıl birleştirilmesi gerektiğini açıklamaya çalışan modellerden biridir. Model birbirleriyle doğrusal olarak bağlı olmayan sekiz ögenin birleşmesiyle oluşmuştur. Bu öğeler; katılımcılar, oyuncu deneyimleri, sosyokültürel çevre, oyunun dinamik öğeleri, değişim, yönetim, teknoloji, oyunun kullanımıdır.

Genel tasarım modellerinde bulunan analiz, tasarım, geliştirme, uygulama ve değerlendirme basamaklarına ek olarak bir ön analiz basamağına sahiptir. Modelin temelleri bulanık mantık göz önüne alınarak şekillendirilmiştir. Modelin geliştirilmesi esnasında gerçek hayat deneyimlerinden elde edilen veriler kullanılmıştır. Modelin aşamaları şu şekilde özetlenebilir:

Ön Analiz Aşaması: Bu aşamada değişebilir bir hedef grup belirlenir, hedef grup için onların önceki deneyimlerine bağlı olarak hedef konu seçilir. Küçük çaplı bir literatür incelemesi yapılarak seçilen konunun oyun benzeri öğrenme ortamı oluşturmak için uygun olup olmadığı araştırılır. Seçilen konuya göre belirlenen hedeflerin değişebilirliği gözden geçirilir. Konu alan uzmanlarının ve hedefi temsil eden grupların görüşme yoluyla görüş ve önerileri alınır. Yazılım geliştirme araçları araştırılır ve analiz edilir. Farklı oyunlar analiz edilir.

Analiz Aşaması: Bu aşamada, ihtiyaç, öğrenen, içerik, amaç ve duruma göre maliyet, risk analizleri yapılarak ön analiz kısmında başlanan oyun analizi derinleştirilir.

Tasarım ve Geliştirme Aşaması: Bu aşamada senaryolar belirlenerek içerikle ilgili uzman görüşü alınır. Motivasyon, geri bildirim, değerlendirme bileşenleri oluşturulur. Destek belgeleri ve veri toplama araçları hazırlanır.

Değerlendirme aşamasında konu alanı uzmanları ve hedef kitleyle görüşülerek biçimlendirici değerlendirme yapılır. Değerlendirme sonucunda elde edilen bulgulara göre gerekli düzeltmeler yapılır (Akıllı \& Çağıltay, 2006). 


\section{Oyun Nesnesi Modeli}

Oyun Nesnesi Modeli (GOM - Game Object Model) ilk kez Amory tarafindan 1999_ 2001 yıllarında tanımlanmıştır. GOM, nesne yönelimli programlamayı temel alarak öğrenmenin pedagojik boyutları ile oyun elemanları arasındaki ilişkiyi açıklamaya çalışan bir modeldir. Sistem, miras alma, çok biçimlilik ve kapsülleme gibi nesne yönelimli programlama öğelerini içerir.

Modelin ilk sürümü 2001 yılında sunulmuş, modelin kullanılmasıyla birlikte eksikliklerin değerlendirilip giderilmesiyle ve bakış açısındaki değişmeler ve gelişmeler ile beraber 2007 yılında ilk sürümü de kapsayan daha geniş bir model haline getirilmiştir. Amory (2007)'e göre eğitsel oyunlar, bağlama uygun, heyecan verici, araştırmaya yönlendiren, katılıma teşvik eden ve karmaşık mücadelelerde gerçekleşen zor diyaloglar sunmalıdır (Amory, 2007; Akgün \& diğer., 2011).

Modelin şematik gösteriminde yuvarlatılmış dikdörtgenler ile içi dolu ve boş daireler kullanılmıştır. Bu modele göre, eğitsel oyun somut ve soyut ara yüzler aracılığıyla açıklanan bileşenlerden oluşmaktadır. Somut ara yüzler eğitsel oyunun pedagojik ve teorik yapılarına; soyut ara yüzlerse tasarım bileşenlerine karşıllk gelmektedir. Oyun Nesnesi Modelinin ilk versiyonu Şekil 5'te gösterilmiştir.

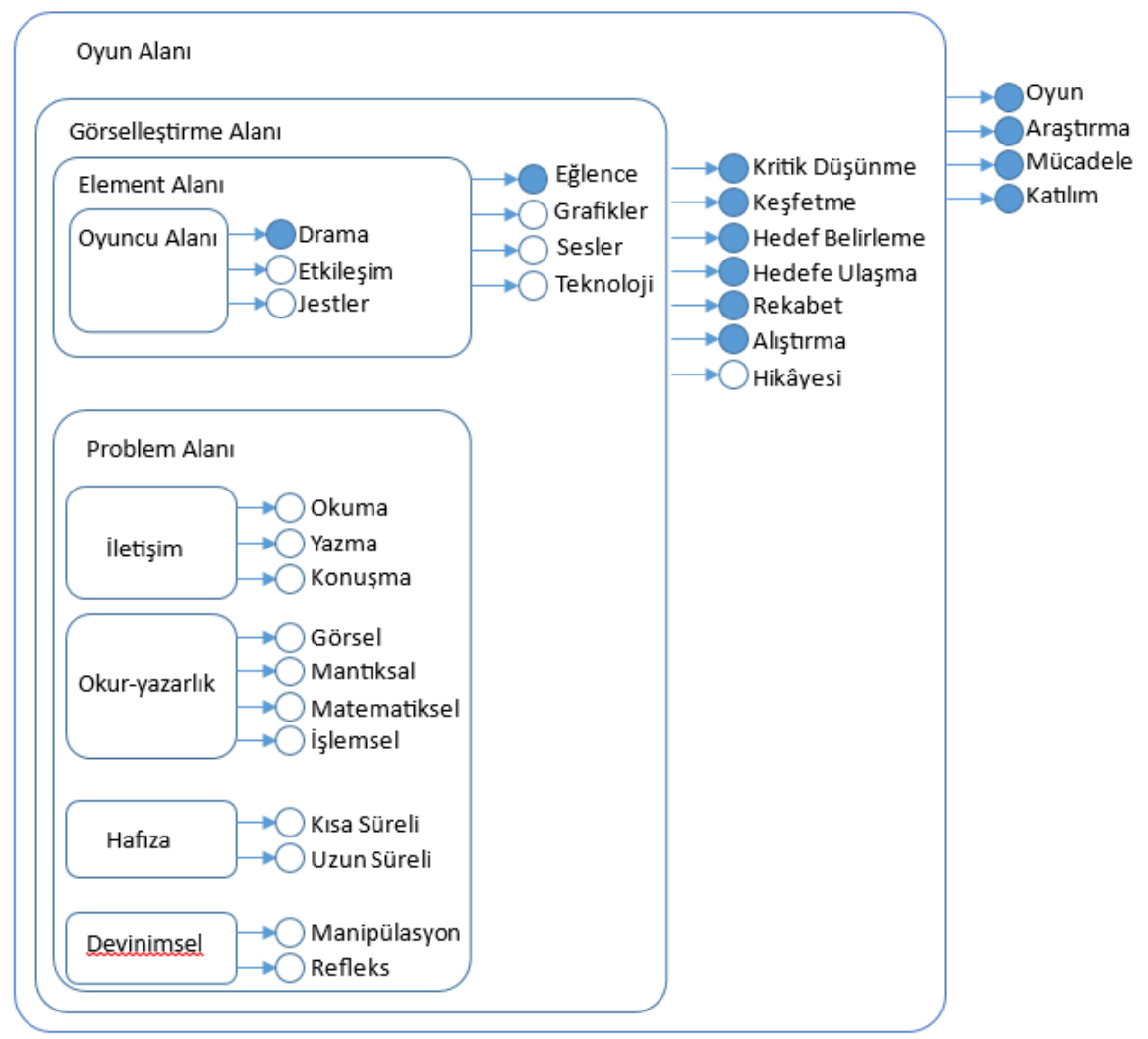

Şekil 5 Oyun Nesnesi Modeli (Amory \& Seagram 2003; Akt. Amory 2007). 
Oyun Nesnesi Modeli akademik macera oyunlarının tasarımında başarı ile kullanılmıştır (Amory, 2007). Oyun Nesnesi Modelinin ikinci sürümü altı temel alandan oluşur. Modelin Oyun Alanı, Görselleştirme Alanı, Element Alanı, Aktör Alanı ve Problem Alanları korunurken; Sosyal Alan bünyesine eklemiştir.

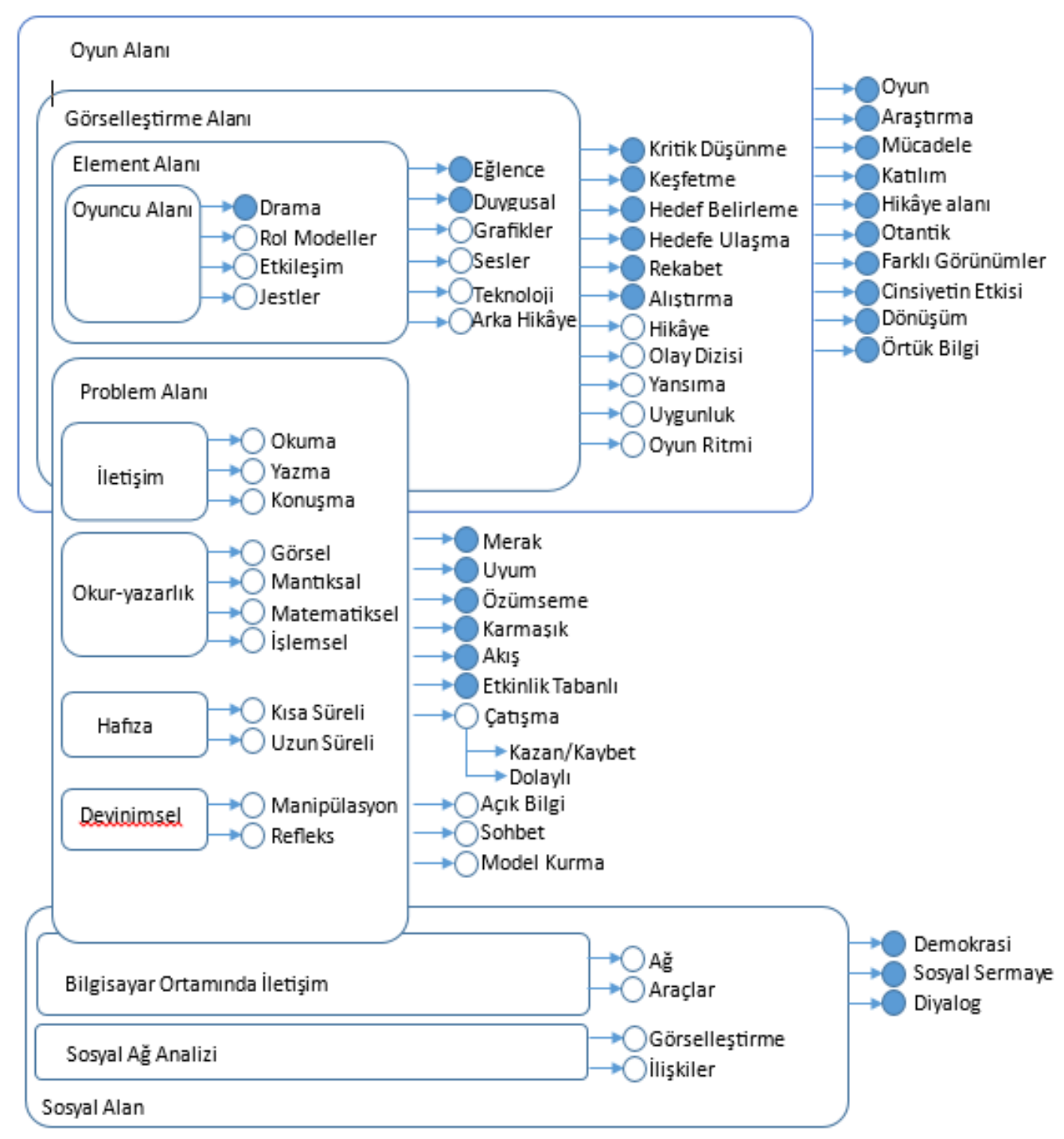

Şekil 6 Oyun Nesnesi Modeli II (Amory, 2007).

GOM II, birbirleriyle ilişkili nesnelerden oluşmaktadır. Bu nesneler mücadele, hikâye, sohbet olmak üzere eğitsel oyunları açıklamak için üç ana alan olarak gruplanmıştır.

\section{Dijital Oyun Tabanlı Öğrenme Modeli}

Dijital Oyun Tabanlı Öğrenme Modeli (DGBL - Digital Game Based Learning) oyun tasarım modelinde oyun, öğrenme içeriklerinin yerleştirildiği bir ortam olarak ele alınmıştır (Zin, Jaafar \& Yue, 2009). Öğrencilerin tarih dersine yönelik motivasyonunu arttırmak için 
çeşitli simülasyonlar kullanarak öğrenciyi, hazırlanan tarihsel ortamın içinde hissettirmek amacıyla yapılan çalışmalar sonucunda DGBL Modeli ortaya çıkmıştır.

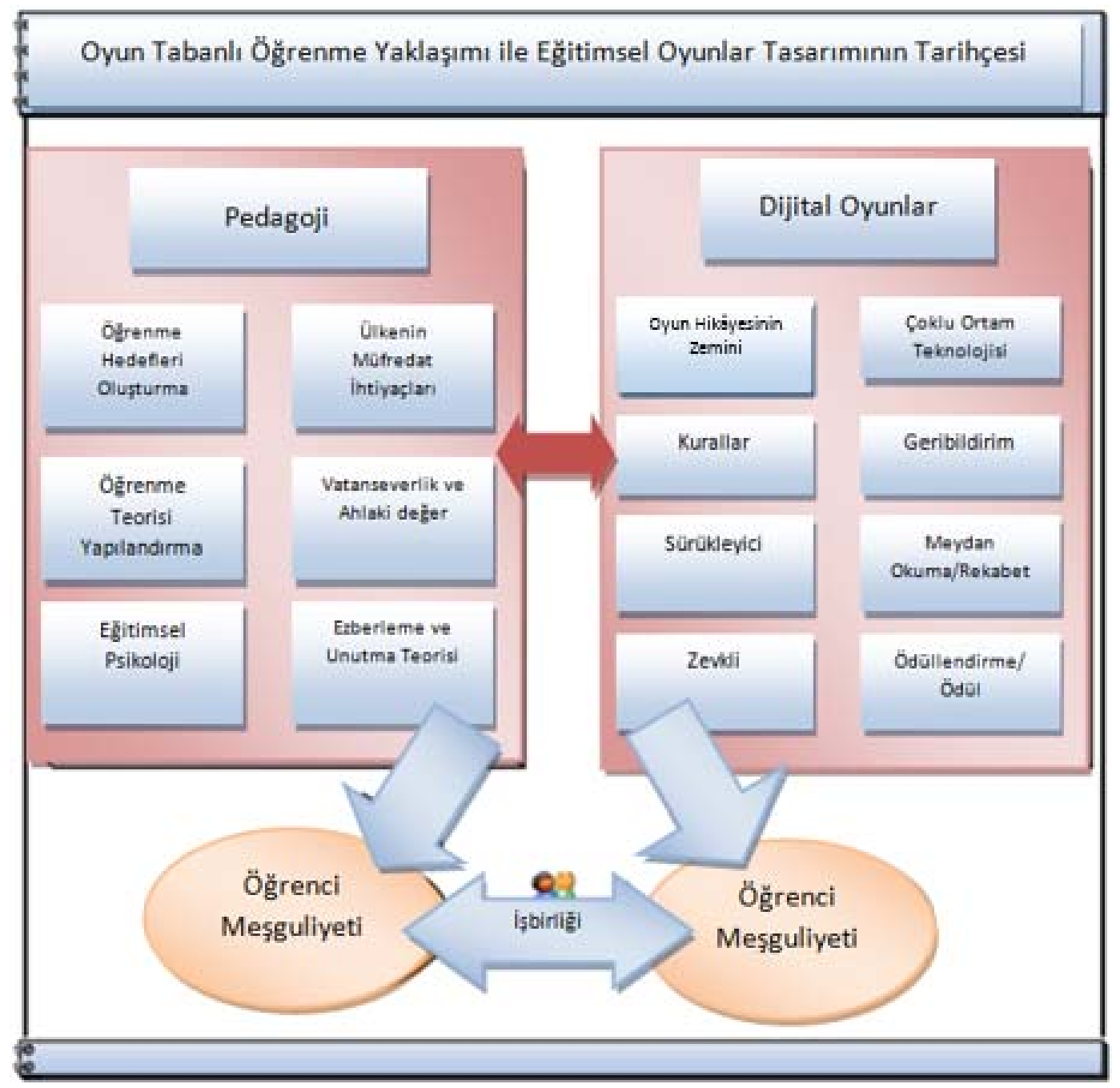

Şekil 7 Eğitsel Tarih Oyunlarının Tasarımı İçin DGBL Modelinde Önerilen Bileşenler.

Model, tarih öğretimi için geliştirilecek bir oyunun, pedagojik bölüm ve dijital oyun bölümü olmak üzere iki temel bileşenden oluşması gerektiğini belirtmektedir. DGBL Modeli, bu bileşenler dikkate alınarak tasarım için beş basamaklı bir yapı sunmaktadır. Genel tasarım modellerine benzer olarak analiz, tasarım, geliştirme, kalite kontrolü, uygulama ve değerlendirme basamaklarından oluşmaktadır. Modelin basamakları ve her basamağın alt görevleri Şekil 8'de verilmiştir (Zin, Jaafar \& Yue, 2009; Akgün \& diğer., 2011). 


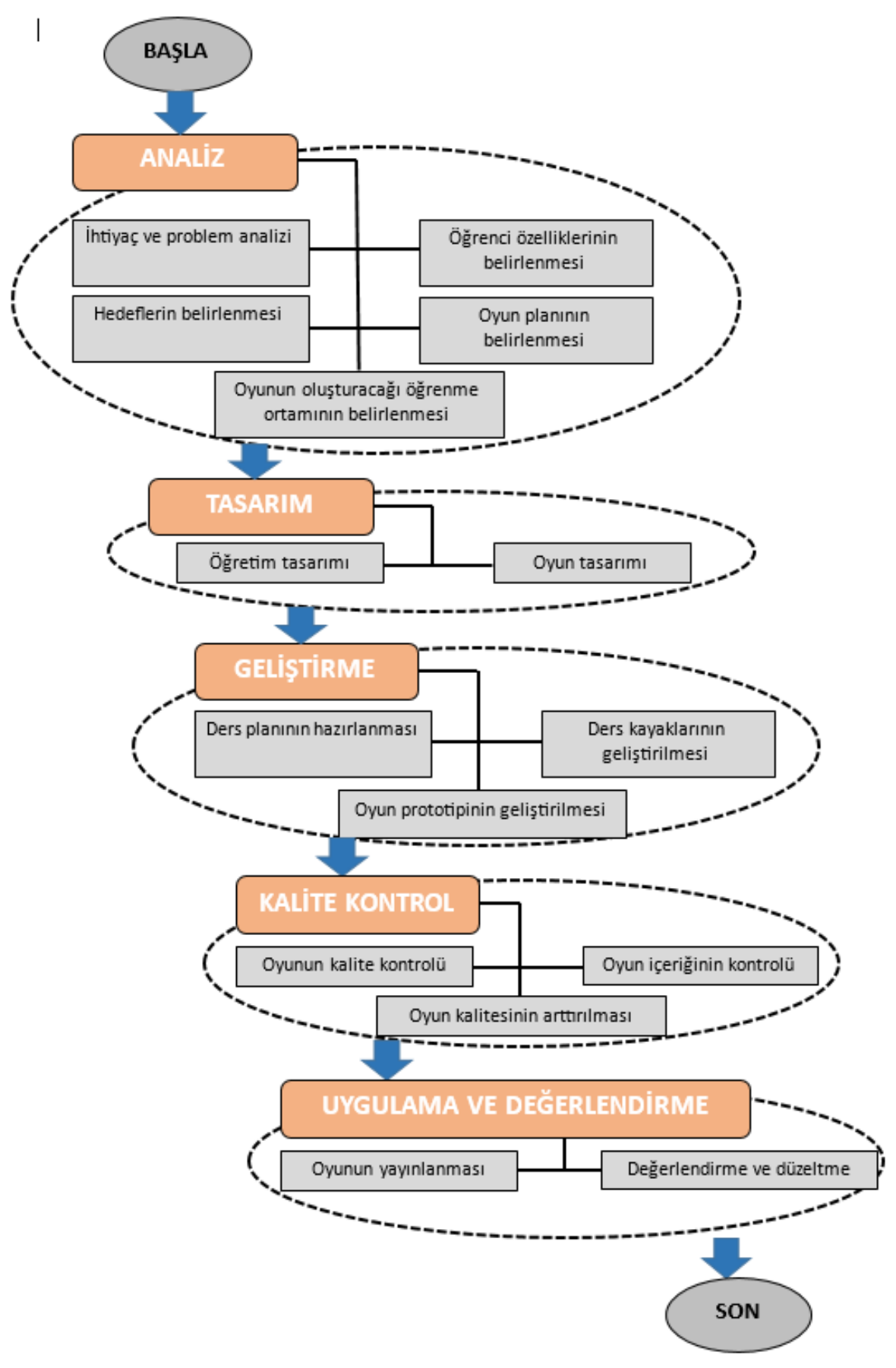

Şekil 8 DGBL Modeli.

\section{Oyun Meydana Getirme Modeli}

Oyun Meydana Getirme Modeli (Game Achievement Model - GAM), GOM'un eğitsel oyun tasarlamak ve üretmek için açıkça belirtmediği bir çerçeve sunmak üzere geliştirilmiştir. GOM ara yüzünün çerçevesi, oyunun kurgusudur ve bundan dolayı bu ara yüz oyun geliştirmenin temelini oluşturmalıdır. Şekil 9'da öncelikli öğrenme hedefleri, hikâye özeti, 
etkinliklerin tasarlanmasında nasıl kullanılması gerektiği gösterilmiştir. Bu etkinlik ya da olaylar GAM'ın başlangıç noktasını oluştururlar (Amory \& Seagram, 2003).

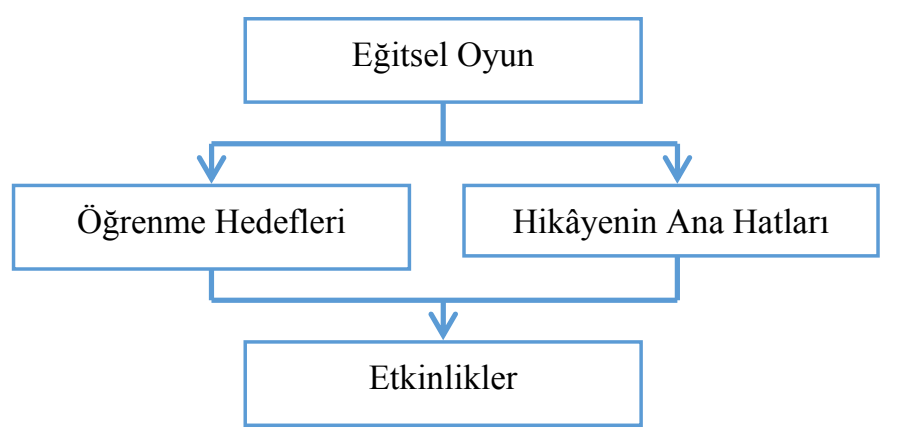

Şekil 9 GAM’a göre eğitsel oyunun etkinliklerini oluşturan iki temel faktör.

$\mathrm{Bu}$ modele göre, bilgisayar oyunları da tıpkı filmlerde olduğu gibi bir dizi etkinlikten oluşmalıdır. Ancak bir film içinde etkinlikleri ayırt etmek zor iken geleneksel oyunlarda etkinliklerin ayrımı kolayca fark edilebilir. Şekil 10'da her eylemin bir amacı ve hikâyenin bir parçası olduğu ve sahnenin bunlara bağlı olarak tasarlanması gerektiği gösterilmiştir.

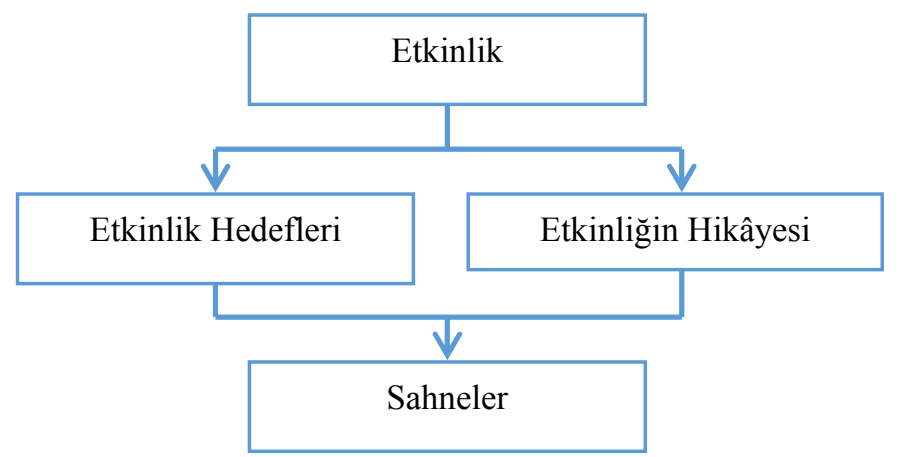

Şekil 10 Oyun içindeki sahnelerin oluşturulması sürecindeki bileşenler.

Bir sahneyi oluşturan üç alan bulunmaktadır: Öğeler, Oyuncular ve Problemler. Tablo 2'de sahneyi oluşturan bu üç alan, alt özellikleriyle birlikte gösterilmiştir (Amory \& Seagram, 2003).

Tablo 2 GAM Modelinde Sahneyi Oluşturan Üç Alan ve Alt Öğeleri.

\begin{tabular}{llc}
\hline & \multicolumn{2}{c}{ SAHNE } \\
\hline Öğeler & Aktörler & Problemler \\
\hline Grafik & Açıklama & Okur Yazarlık Yeteneği \\
Ses & Etkileşim & Görsel \\
Teknoloji & Jestler & Mantıksal \\
& Diyalog & Matematiksel \\
& & Bilgisayar \\
& & Hafiza \\
& & Kisa süreli \\
& & Uzun süreli \\
\hline
\end{tabular}


Model, eğitsel bir oyun geliştirmek için gerekli olan yaratıcılık gibi yetenekleri yok saymadan hikâye anlatımını ve grafik tasarımı içeren iki yönlü kavramsal bir çerçeve sunmaktadir (Amory \& Seagram, 2003).

\section{Deneyimsel Oyun Modeli}

Kiili (2005a) tarafından, oyun tasarım sürecine eğitsel kuramları entegre ederek eğitsel oyun tasarımcılarına, oyunlarla öğrenme mekanizmasını anlamada yardımcı olması için Deneyimsel Oyun Modeli (EGM- Experiential Gaming Model) önerilmiștir. Modelin Kiili (2005b) tarafından geliştirilmiş ikinci bir sürümü bulunmaktadır. EGM, Csikszentmihalyi’nin (1975) akış teorisini ve oyun tasarımını temel almaktadır.

Modelin amacı, oynanış ile deneyimsel öğrenmeyi ilişkilendirerek akış deneyimini kolaylaştırmaktır. Model, öğrenmeyi deneyim yoluyla doğrudan oyun dünyası içinde döngüsel bir süreç olarak tanımlar. İkinci sürümde bu döngüsel sürece bir de tasarım döngüsü eklenmiştir.

Kiili, öğrenmenin sadece bilişsel değil, davranışsal da olduğunu vurgulayarak bilişsel yapıların oyun dünyası içinde yapılan etkinlik ve pratiklerle desteklenmesi gerekliliğini ortaya koymuştur. Deneyimsel Oyun Modeline göre, oyuncular akış deneyimi yaşadıklarında oyuna daha çok bağlanmaktadır. Bu nedenle, Deneyimsel Oyun Modeline göre, bir oyun tasarlanırken, akış deneyimine katkıda bulunacak şekilde tasarlanmalıdır.

Model, fikir üretme döngüsü, deneyim döngüsü ve mücadele öğelerini içerir. Modelin yapısı Şekil 11'deki gibi insan dolaşım sistemine benzetilerek geliştirilmiştir. Eğitim amaçlarına dayalı zorluklar, modelinin kalbini oluşturmaktadır. Kalp, oyuncuya çeşitli mücadele alanları ve problemler yaratarak motivasyonu sağladığı gibi, oyuncunun oyuna katılımını da arttırır. Oyuncu mücadele sırasında karşılaştığı zorlukları aşmak için döngü içinde çözümler üretir. Burada oyuncu, öncelikle hiçbir kısıtlama olmaksızın birincil, yani yaratıcı fikirler geliştirir. Birincil fikirlerin, çözümü içeren fikirlere dönüşmesiyle küçük dolaşım tamamlanmış olur. Model'e göre, fikir üretme süreci gruplar halinde gerçekleştirildiğinde daha verimli olmaktadır. Fikir üretme aşamasından sonra, oyuncu ürettiği çözümleri büyük dolaşıma karşılık gelen deneyim döngüsünde uygulayarak dener ve eylemlerinin sonuçlarını gözlemler. Deneyim döngüsünde, oyunun kullanılabilir ve açık hedefler sunması gerekir. Ayrıca, oyun akış deneyimini kolaylaştırabilmek için uygun ve 
belirsiz olmayan geri bildirimler sağlamalıdır. Buna ek olarak odaklanmış dikkat akış deneyiminde önemli bir faktördür. Geri bildirimlerin oluşturacağı yansitıcı gözlemler, problemlere daha iyi çözümler geliştirilmesini ve yeni şemaların oluşturulmasını sağlayabilir. Çözümlerin denenmesi aşamasında oyuncunun, oyun ve konu üzerindeki kontrol becerisi gelişir ve çözüme ilişkin şema güçlendirilir. Büyük dolaşım da böylece tamamlanmış olur.

Kalp, her oyuncunun beceri düzeyine uygun olarak farklı zorluk seviyeleri sağlamalıdır. Ayrıca oyunun zorluk düzeyleri dengeli olmalı ve bazen çok zor bazen çok kolay olmamalıdır.

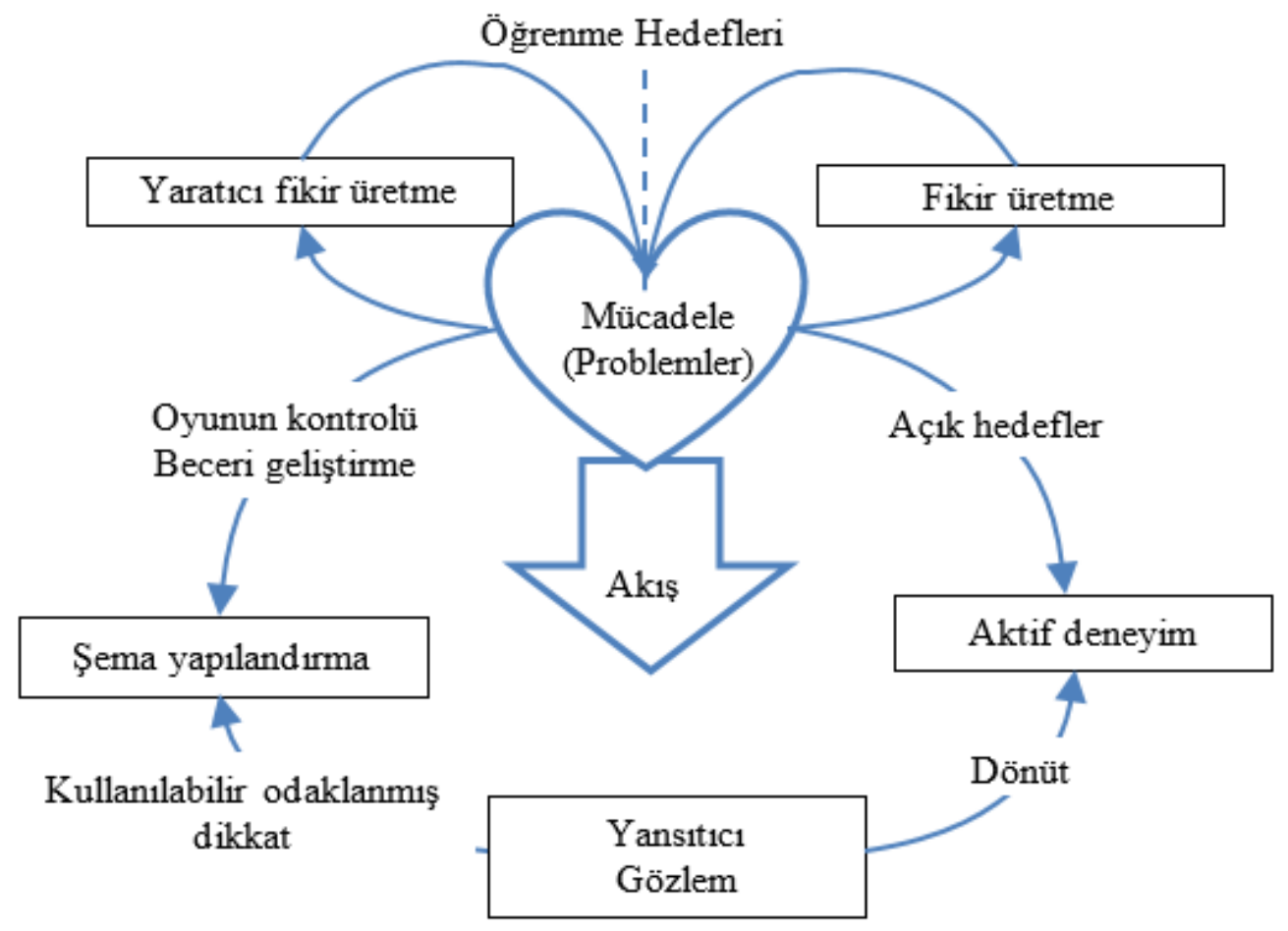

Şekil 11 Deneyimsel Oyun Modeli I (Kiili 2005a).

Genel olarak, kalbin amacı oyuncuya mücadele edeceği bir alan sunarak fikir ve deneyim döngüsüne girişi sağlamaktır. Fikir döngüsünün amacı yeni ve yaratıcı fikirler ortaya çıkarmak, deneyim döngüsünün amacı ise ortaya çıkan fikirlerin işe yarayıp yaramadığını test ederek fikirleri temizlemektir.

Deneyimsel Oyun Modeli, eğitsel oyunlar tasarlamak ve analiz etmek için kullanılabilir. Ancak, model eğitim kuramları ve oyun tasarımı arasında bir bağlantı olarak çalışır ve bir eğitsel oyun tasarım projesine baştan sona yol gösteremez.

Kiili, eğitsel oyun tasarımcılarının ihtiyaçlarını daha iyi karşılayabilmek için Deneyimsel Oyun Modelinin gözden geçirilmiş bir sürümünü sunmuştur. $\mathrm{Bu}$ sürümde 
modelin tasarım döngüsü genişletilmiştir. Böylece, sadece oyunlarla öğrenme sürecini tanımlamak yerine, oyun tasarım ve geliştirme süreci de modele dâhil edilmiştir. Ayrıca tasarım döngüsüne ek olarak akış elemanları da ilave edilmiştir. Deneyimsel Oyun Modelinin ikinci sürümü Şekil 12'de sunulmuştur.

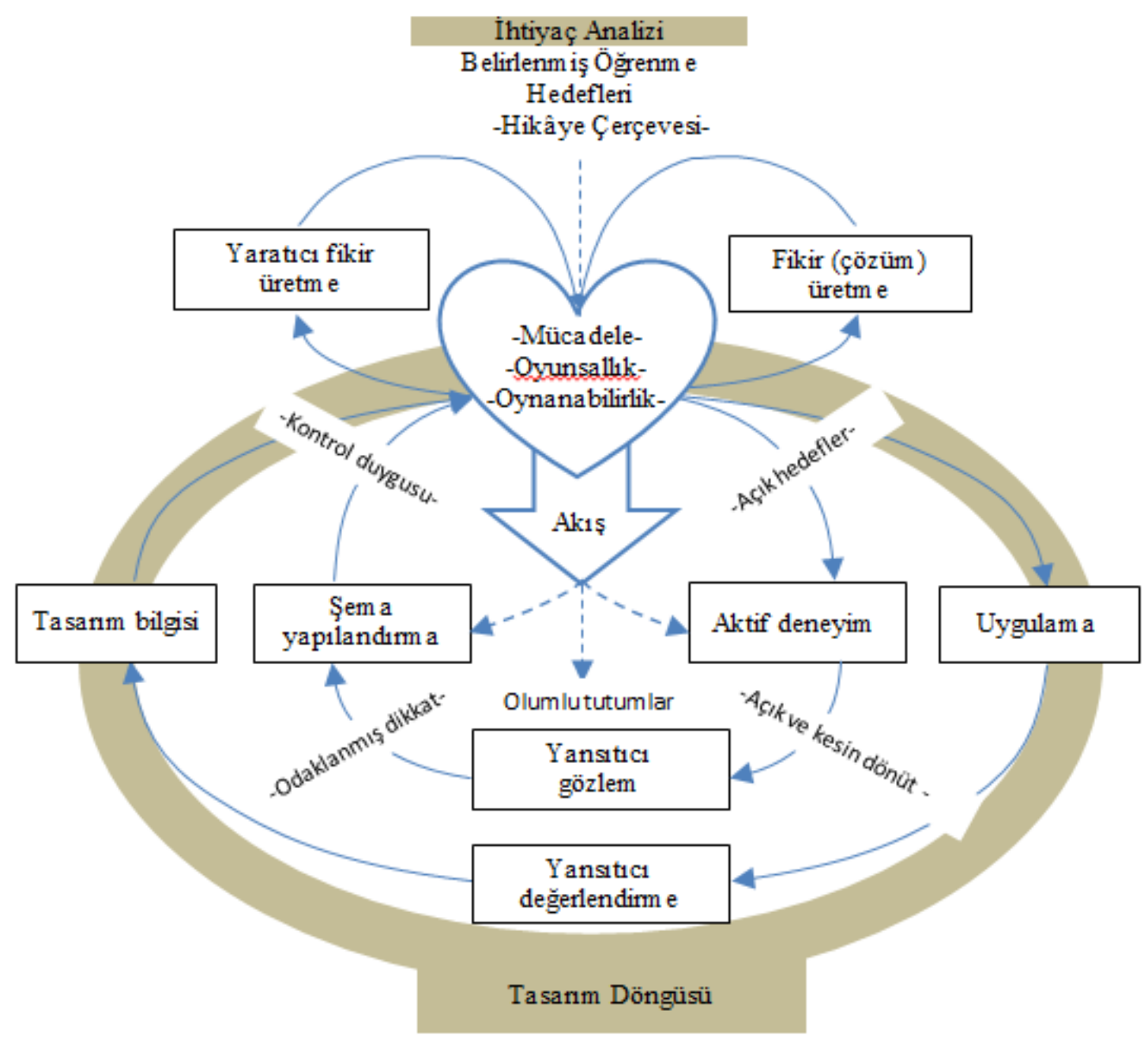

Şekil 12 Deneyimsel Oyun Modelinin İkinci Sürümü (Kiili, 2005b).

Deneyimsel Oyun Modelinin ikinci sürümünü oluşturan öğeler; mücadele, açık hedefler, dönüt, odaklanmış dikkat, kontrol duygusu, oynanabilirlik, hikâye çerçevesi ve oyunsallıktır. Kiili (2005b), bu öğeleri Tablo 3'teki gibi açıklamıştır.

Akış öğeleri, oyun tabanlı öğrenmeyi destekleyen bir yapı sunarlar. Akış deneyimi, kişilerin fiziksel veya zihinsel bir zorluğu aşmak için gönüllü olarak sınırlarını zorladıklarında etkili olmaktadır. Bu durum akış deneyimini desteklemek için oyuncunun kolay ve zahmetsizce sonuca ulaştığı bir eğitsel oyun geliştirilmesi gerektiği şeklinde yorumlanmamalıdır. Aksine, eğitsel oyunlar oyuncunun zorlukları aşabilmek için sınırlarını 
zorlamalıdır. Akış deneyiminin bu doğası, eğitsel oyun tasarlamak için uygun bir tasarım yöntemi sunar. Böylece yaşam boyu öğrenme stratejisine uygun olarak oyuncular başka bir ödül beklemeksizin eğitsel oyunun kendisini bir ödül olarak görür ve oyun oynayarak öğrenebilirler.

Tablo 3 EGM öğelerinin açıklaması.

\begin{tabular}{|c|c|}
\hline Mücadele & $\begin{array}{l}\text { Zorluklar oyuncunun beceri düzeyine uygun olmalıdır. } \\
\text { Zorluk seviyesi oyuncunun ilerleme seviyesine uygun olarak değişmelidir. } \\
\text { Oyun, becerilerin gelişmesini desteklemeli ve gelişen becerileri ödüllendirmelidir. } \\
\text { Oyun, yeni problemleri uygun hızda sunmalıdır. } \\
\text { Problemler öğrenme hedeflerine uygun olmalıdır. }\end{array}$ \\
\hline Açık hedefler & $\begin{array}{l}\text { Oyun, en başında ana hedefi açıkça ortaya koymalıdır. } \\
\text { Oyun, alt hedefleri uygun hızda ve açıkça vermelidir. }\end{array}$ \\
\hline Dönüt & $\begin{array}{l}\text { Oyuncunun eylemlerine kesin ve anında dönüt verilmelidir. } \\
\text { Oyun, hedeflere yönelik olarak dönüt sağlamalıdır. } \\
\text { Oyunun durumu hakkında bilgi vermelidir. }\end{array}$ \\
\hline Odaklanmış dikkat & $\begin{array}{l}\text { Oyun, oyuncunun dikkatini çekmeli ve oyun boyunca bu dikkati korumalıdır. } \\
\text { Oyuncunun dikkati öğrenme amaçlarına yönelik olmalıdır. } \\
\text { Oyuncu, dikkatini dağıtan gereksiz şeylerle meşgul edilmemelidir. } \\
\text { Oyuncuya bilişsel yapısına uygun olarak yüklenilmelidir. }\end{array}$ \\
\hline Kontrol duygusu & $\begin{array}{l}\text { Oyunun arayüzü, kontrolün oyuncuda olduğu hissini vermelidir. } \\
\text { Oyuncunun özgürlüğ̈̈ çok kısıtlanmamalıdır. } \\
\text { Oyuncunun, oyun içindeki düzeltilmesi zor hataları önlenmelidir. } \\
\text { Oyuncu, hata düzeyi çok az olan başarı düzeyine ulaşabilmelidir. } \\
\text { Oyunda ilerlemenin, oyuncunun elinde olduğu hissi verilmelidir. }\end{array}$ \\
\hline Oynanabilirlik & $\begin{array}{l}\text { Kullanıcı arayüzü ve kontroller kolay öğrenilmeli ve kullanılmalıdır. } \\
\text { Oyun akılda kalıcı olmalıdır. } \\
\text { Hedeflere ulaşmak için uygun araçlar sağlamalıdır. } \\
\text { Gereksiz ses ve grafiklerle oyuncu aşırı yüklenmemelidir. } \\
\text { Animasyonlar en üst düzeyde fayda sağlamalıdır. } \\
\text { Oyuncu, üst düzey yapılarla şaşırtılmamalıdır. } \\
\text { Grafikler ve sesler uyumlu olmalıdır. } \\
\text { Oyuncuların topluluk oluşturması desteklenmelidir. }\end{array}$ \\
\hline Hikâye çerçevesi & $\begin{array}{l}\text { Hikâye, hedefleri algılamak ve problemleri yapıya entegre etmek için kullanılmaldır. } \\
\text { Oyuncunun karşıllaştığı problemler hikâyeyle uyumlu olmalıdır. }\end{array}$ \\
\hline Oyunsallık & $\begin{array}{l}\text { Kazanımlar, oyundaki etkinlerle bağlantılı ve yapıcı olmalıdır. } \\
\text { Oyun doğrusal olmayan geniș bir mücadele sunmalıdır. }\end{array}$ \\
\hline
\end{tabular}

Genellikle, eğitsel oyun geliştirmek eğitim kurumlarının göze alamayacağı kadar büyük kaynaklar gerektirdiği için Deneyimsel Oyun Modeli zaman ve maliyet verimliliği ilkesi gözetilerek tasarlanmıştır. Modele ilave edilen tasarım döngüsünün amacı, tasarımcıları yönlendirmek ve çalışmalarını kolaylaştırmaktır. Tasarım döngüsünün çok temel öğeler barındırması farklı oyun türlerini içerecek şekilde özelleştirilebilmesini sağlamak içindir. Ayrıca, Crawford (1984)'a göre, oyun tasarımı tek bir yönteme indirgenemeyecek kadar karmaşık bir süreç olduğundan, bu yaklaşım makul bir çözüm olarak görülebilir.

Tasarım döngüsü, öğrencilerin ihtiyaçlarını ve tasarım çözümlerini tanımlamak için ihtiyaç analizi ile başlar. Modelin döngü yapısı ihtiyaç analizi sürecini de açıklamaktadır. 
Yaratıcı (birincil) düşünme aşamasında tasarımcı mümkün olduğunca yaratıcı çözümler geliştirmeye çalışır. Ortaya çıkan fikirler; akış deneyimi öğeleri, öğretim tasarımı ilkeleri ve konu alanının kısıtlamaları dikkate alınarak değerlendirilir ve çözüm olarak geliştirilir. Bu aşamadan sonra, geliştirilen çözümler, oyuncuyla erken deneyim yaşamak için hızla uygulanır. Hızlı protoptip geliştirme, tasarımcıya çabuk bir değerlendirme yapma imkânı sunar. Prototip geliştilmesi, son kullanıcıyı tasarım sürecine dahil etme avantajı sağlar. Bir seferde mükemmel sonuca ulaşmayı değil, yapılan değişikliklerle ürünün aşama aşama son halini almasını amaçlar.

Yansıtıcı değerlendirme aşamasında, gerçekleştirilen deneyler değerlendirilir. Odak ise oyun dünyasının ve deneylerin analizidir. Oyun dünyasının analiz edilmesindeki amaç, oyundaki özelliklerin kullanımının incelenmesidir. Deneylerin analizindeki amaç ise oyuncuların deneyimlerinin, oyun hakkındaki duygularının ve algılarının analiz edilerek tasarım için yeni fikirler ortaya çıkartılmasını sağlamaktır.

Tablo 4'te tasarım döngüsünde her bir aşama (ihtiyaç analizi, uygulama, yanstıcı değerlendirme, tasarım bilgisi); ana görevler, olası yöntemler, çıktılar ve riskler için özetlenmiştir.

Tablo 4: Tasarım Döngüsünün Aşamalarının Özeti.

\begin{tabular}{|c|c|c|c|c|}
\hline & İhtiyaç Analizi & Uygulama & $\begin{array}{c}\text { Yansitıci } \\
\text { Değerlendirme }\end{array}$ & Tasarım Bilgisi \\
\hline Görevler & $\begin{array}{l}\text { İhtiyaçları belirlemek } \\
\text { ve yaratıcı çözüm } \\
\text { tasarımları } \\
\text { oluşturma. }\end{array}$ & $\begin{array}{l}\text { Tasarım çözümlerini } \\
\text { uygulama. }\end{array}$ & $\begin{array}{l}\text { Uygulanabilir } \\
\text { çözümleri } \\
\text { değerlendirme. } \\
\text { Daha derinlemesine } \\
\text { anlama. }\end{array}$ & $\begin{array}{l}\text { Test edilmiş çözümlerin } \\
\text { tasarım bilgisini } \\
\text { yapılandırma. }\end{array}$ \\
\hline Yöntemler & $\begin{array}{l}\text { Akış öğelerinin, } \\
\text { öğretim tasarımı } \\
\text { ilkelerinin ve } \\
\text { bağlamsal faktörlerin } \\
\text { analiz edilmesi. }\end{array}$ & Hizlı prototipleme. & $\begin{array}{l}\text { Oyun dünyasının ve } \\
\text { deneyimlerin analiz } \\
\text { edilmesi. }\end{array}$ & $\begin{array}{l}\text { Başarılı ve başarısız } \\
\text { çözümlerin raporlanması. }\end{array}$ \\
\hline Çıktılar & $\begin{array}{l}\text { Eğitsel, teknik ve } \\
\text { psikolojik tasarım } \\
\text { ilkeleri ve çözümler. }\end{array}$ & $\begin{array}{l}\text { Akışı tetikleyen } \\
\text { eğitsel oyun. }\end{array}$ & $\begin{array}{l}\text { Oyun dünyasının } \\
\text { özellikleri ve } \\
\text { kullanıcı } \\
\text { deneyimleri. }\end{array}$ & $\begin{array}{l}\text { Gelecekteki ihtiyaçlar } \\
\text { için tasarımcı örnekleri. }\end{array}$ \\
\hline Riskler & $\begin{array}{l}\text { Oyun tasarımı ve } \\
\text { eğitimin anlamlı bir } \\
\text { şekilde } \\
\text { birleştirilmesi. }\end{array}$ & $\begin{array}{l}\text { Oyunculara çok } \\
\text { erken açıklama } \\
\text { yapılması. }\end{array}$ & $\begin{array}{l}\text { Uygun olmayan } \\
\text { yöntemler: Hatalı } \\
\text { sonuçlar. }\end{array}$ & $\begin{array}{l}\text { İçerikle ilgili doküman } \\
\text { yokluğu. Aktarım } \\
\text { problemleri. }\end{array}$ \\
\hline
\end{tabular}

Oyun tasarım modellerinin tamamı göz önüne alındığında, ihtiyaç analizi yapılarak senaryonun oluşturulması ve eğitsel amaçlar doğrultusunda oluşturulan mücadele öğelerinin oyuna yerleştirilmesi öngörülmektedir. Oyuncuların mücadeleler boyunca yaptıkları eylemlere açıklayıcı dönütler vererek oyun oynarken öğrenmeleri hedeflenmektedir. 


\section{Sarmal Ĕ̌itsel Oyun Tasarım Modeli}

EFM, FIDGE, EGM, GOM, DGBL modelleri incelenerek geliştililmiş bir modeldir. Eğitsel oyun geliştirmenin "oyun" ve "eğitsel” olarak iki kısımdan oluştuğunu ve iki bileşen arasında sarmal bir ilişkinin olduğu fikrinden yola çıkmaktadır. Her aşamada yapılan çalışmaların içdeğerlendirme sürecine tabi tutularak geri süreç içerisinde geri dönüş yapılmasını en aza indirgemeyi ön görmektedir (Akgün \& diğer., 2011).

Şekil 13'te gösterildiği gibi eğitsel süreç ve oyun geliştirme süreci birbirlerini destekleyen basamakalar olarak ele alınmış ve geriye dönük bağlantılarla iç değerlendirme sisteme dahil edilmiştir.

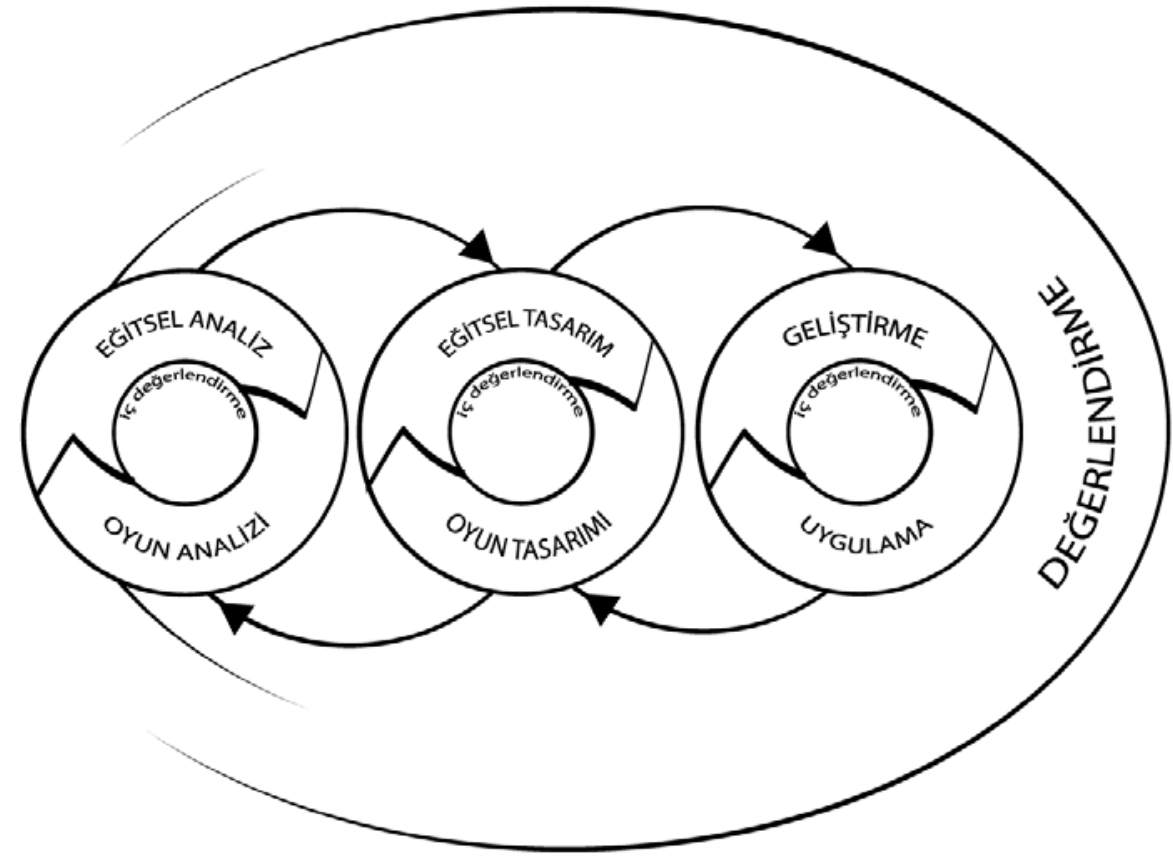

Şekil 13 Eğitsel Oyun Tasarımı Döngüsü (Akgün \& diğer., 2011).

Şekil 14’te tasarım döngüsünün tasarım sürecine nasıl dönüştürüleceği gösterilmiştir. 


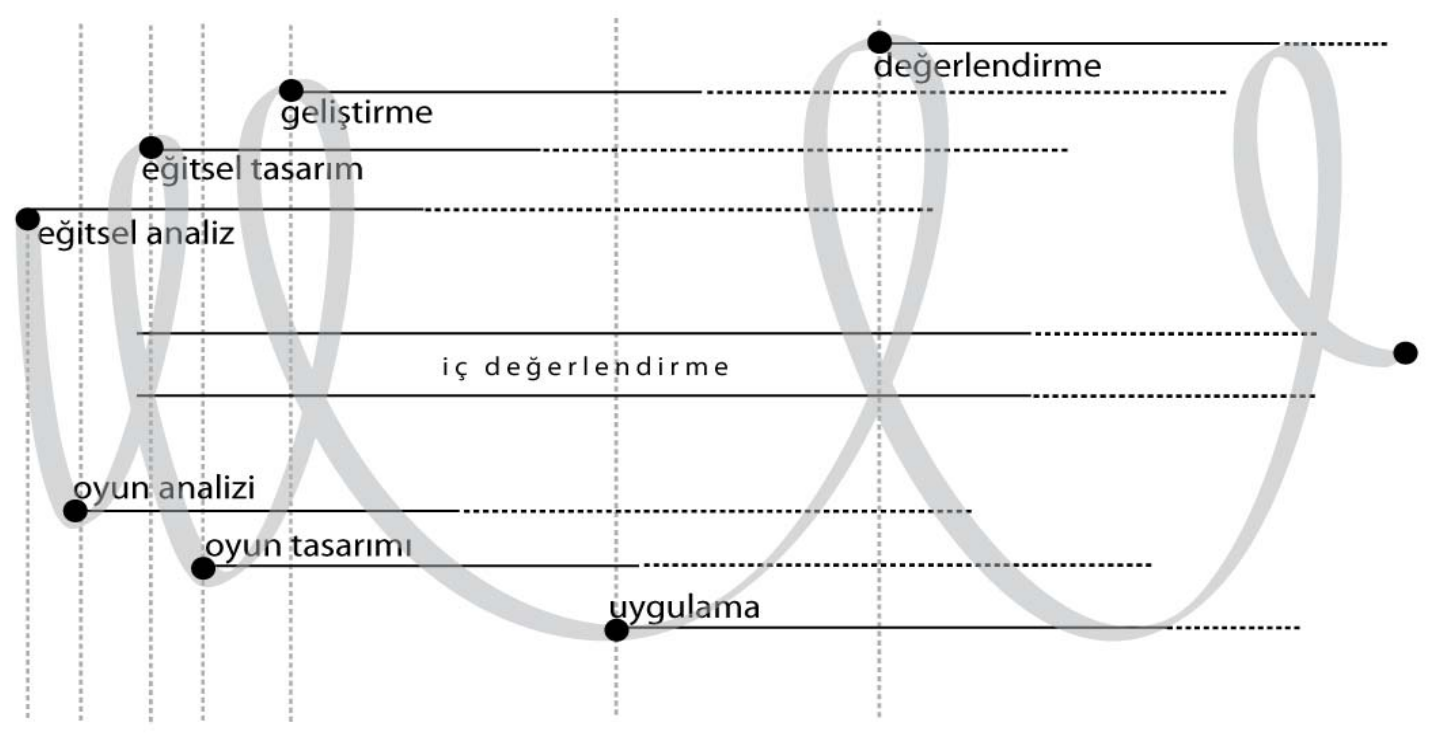

Şekil 14 Eğitsel Oyun Tasarım Süreci (Akgün \& diğer., 2011).

\section{Fen ve Matematik Ĕgitiminde Bilgisayar Oyunları}

Fen bilimlerinin karmaşık doğası, fen öğrenenler için zor bir süreç oluşturmaktadır. Öğrenciler de fen öğrenmenin zor olduğu algısını kabullenmekte ve bu düşünceyi değiştirmek pek mümkün olmamaktadır (Yağbasan \& Gülçiçek, 2003).

Özellikle son 20 yılda fen alanında yapılan araştırmalarda geleneksel yöntemlere göre öğrenim gören öğrencilerin pek çok kavram yanılgısına sahip oldukları belirlenmiştir (Hançer, 2007). İlköğretimin ilk kademelerinden itibaren üniversite seviyesi dahil her seviyede öğrencinin çeşitli kavram yanılgıları ve kavramları anlama düzeyinde yetersizlikleri vardır (Osborne, 1981; Shipstone ve diğer., 1988; Chambers \& Andre, 1997; Ateş \& Polat, 2005). Fen alanındaki bu kavram yanılgılarından bazıları, kalıtım, maddenin tanecikli yapısı, basit elektrik devreleri şeklindedir (Haidar \& Abraham, 1991; Lee \& arkadaşları ,1993; Ayas, 1995, Küçüközer, 2004).

Öğrencilerin matematik alanındaki kavram yanılgıları da fen alanındaki durumlarıyla paralellik göstermektedir. Öğrenciler matematikte temel kavramları tanımlamada, kavramları sözel olarak ifade etmede ve kavramlar arasındaki farkı belirlemede güçlükler yaşamaktadırlar (Kar, Çiltaş \& Işık, 2011). 
Bunun yanında öğrencilerin fen ve matematik derslerine yönelik tutumları ve motivasyonları da çok olumlu değildir (Kurnaz \& Yiğit, 2010; Alkan, 2006; Çokadar \& Külçe, 2008; Çakır, Şenler \& Taşkın, 2007).

Fen ve matematik derslerinin, başarısı en düşük derslerden olmaları, bu alanda çok sayıda kavram yanılgısının bulunması, öğrencilerin bu derslere karşı tutum ve motivasyonlarının diğer derslere oranla daha düşük olması gibi sebepler göz önüne alındığında; boş zamanlarının çoğunu bilgisayar başında oyun oynayarak geçiren öğrencilerin oyunlara yönelik ilgilerinin, derslerle ilgili etkinliklerin bulunduğu eğitsel oyunlara yoğunlaştırılması önemlidir. Öğrencilerin oyunlara yönelik ilgisinin fen ve matematik dersine yönelik tutum, motivasyon ve başarılarını olumlu yönde etkileyeceği düşünülmektedir.

\section{Sonuç}

$\mathrm{Bu}$ çalışmada öncelikle bilgisayar oyunu türleri sınıflandırılmış, eğitsel oyun tanımı yapılarak eğitsel oyunların özellikleri incelenmiştir. Daha sonra, literatürde yer alan mevcut oyun tasarım modelleri ve oyun tasarımında sundukları yöntemler ayrıntılı olarak açıklanmıştır. İncelenen yöntemler sırasıyla: EFM (Effective Learning Environment), FIDGE (Fuzzified Instructional Design Development of Game-like Environments), GOM (Game Object Model), (DGBL - Digital Game Based Learning), GAM (Game Achievement Model), EGM (Experiential Gaming Model) ve Sarmal Eğitsel Oyun Tasarım Modeli'dir.

İncelenen bu 7 eğitsel oyun tasarım modelinde genel olarak, genel tasarım modeline uyulduğu ve oyundaki mücadele ve motivasyon unsurlarının tasarlanacak oyunlarda bulunması gerektiğinin öneminden bahsedilmektedir. Her bir tasarım modelinin kendisine göre bir eğitsel oyun geliştirme çevrimini barındırdıkları görülmüştür.

$\mathrm{Bu}$ çalışmada bahsedilen oyun tasarım modelleri, yapılacak bir çalışmanın teorik çerçevesini oluşturmaktadır. Modellerden herhangi biri ele alındığında, modelin baştan sona bir eğitsel oyunu geliştirmeye yetmeyeceği, ancak oyun tasarımcıları için rehberlik edebileceği sonucuna ulaşılmıştır. Ayrıca sunulan modellerin pek azının, bir eğitsel oyun yazılarak modelin çalışmasının test edildiğgi görüşmüştür. Teorik olarak sunulan bu çerçevelerin farklı araştırmacılar tarafından denenmesi ve raporlanması, özellikle fen ve matematik alanında eğitsel oyun geliştirmeye katkıda bulunabileceği umulmaktadır. 


\section{Kaynakça}

Akgün, E., Nuhoğlu, P., Tüzün, H., Kaya, G., \& Çınar, M. (2011). Bir eğitsel oyun tasarımı modelinin Geliştirilmesi. Eğitim Teknolojisi Kuram ve Uygulama, 41-61.

Akıllı, K., \& Çağıltay, K. (2006). An instructional design/development model for the creation of game-like learning environments: Fidge model. Affective and Emotional Aspects of Human-Computer Interaction: Game-based and Innovative Learning Approaches, 93112.

Alessi, S. M., \& Trollip, S. R. (2001). Multimedia for learning: Methods and Development (third ed.). Massachusetts: Allyn \& Bacon: Needham Heights.

Alkan, A. (2006). İlköğretim öğrencilerinin fen bilgisine karşı tutumları. Afyon: Afyon Kocatepe Üniversitesi.

Amory, A. (2007). Game object model version II: A theoretical framework for educational game development. Education Tech Research Dev, 55, 51-77.

Amory, A., \& Seagram, R. (2003). Educational Game Models: Conceptualization and Evaluation. South African , 206-217.

Ang, C. S., \& Rao, R. K. (2008). Computer game theories for designing motivating educational software: A survey study. International Journal on E-Learning, 7(2).

Ateş, S., \& Polat, M. (2005). Elektrik devreleri konusundaki kavram yanılgılarının giderilmesinde öğrenme evreleri metodunun etkisi. Hacettepe Üniversitesi Ĕ̆itim Fakültesi Dergisi (28), 39-47.

AYAS, A. (1995), Lise I kimya öğrencilerinin maddenin tanecikli yapısı kavramını anlama seviyelerine ilişkin bir çalışma, II. Ulusal Fen Bilimleri Eğitimi Sempozyumu, ODTÜ Eğitim Fakültesi, Ankara.

Bakar, A., Tüzün, H., \& Çağıltay, K. (2008). Öğrencilerin eğitsel bilgisayar oyunu kullanımına ilişkin görüşleri: Sosyal bilgiler dersi örneği. Hacettepe Üniversitesi Ĕ̈itim Fakültesi Dergisi, 27-37.

Bartholomew, L. K., M.Sockrider, M., Abramson, S. L., Swank, P. R., Czyzewski, D. I., Tortolero, S. R., . Tyrrell, S. (2006). Partners in school asthma management: Evaluation of a self-management program for children with asthma. Journal of School Health, 76(3), 283-290.

Bayram, S. (1999). Bilgisayar destekli ögretim teknolojileri. İstanbul: Marmara Üniversitesi Teknik Eğitim Fakültesi Yayınları.

Bottino, R., Ferlino, L., \& Travella, M. O. (2006). Developing strategic and reasoning abilities with computer games at primary school level. Computers \& Education, 49(4), 1272-1286.

Brom, C., Preuss, M., \& Klement, D. (2011). Are educational computer micro-games engaging and effective for knowledge acquisition at high-schools? A quasiexperimantal study. Computers \& Education(57), 1971-1988.

Chambers, S., \& Andre, T. (1997). Gender, prior knowledge, interest, and experience in electricity and conceptual change text manipulations in learning about direct current. Journal of Research in Science Teaching (34), 107-123.

Crawford, C. (1984). Art of computer game design. Osborne: McGraw-Hill.

Csikszentmihalyi, M. (1991). Flow: The psychology of optimal experience. Harper Perennial. 
Çakır, N., Şenler, B., \& Taşkın, B. (2007). İlköğretim İkinci kademe öğrencilerinin fen bilgisi dersine yönelik tutumlarının belirlenmesi. Türk Ĕ̈itim Bilimleri Dergisi, 5, 637-655.

Çokadar, H., \& Külçe, C. (2008). Pupil's attitudes towards science: A case of turkey. World Applied Sciences Journal, 3, 102-109.

Dede, Y. (2003). Arcs motivasyon modeli'nin öğrencilerin matematiğe yönelik motivasyonlarına etkisi. Pamukkale Üniversitesi Eğitim Fakültesi Dergisi, 2(14), 173 182.

Demirel, Ö., Seferoğlu, S., \& Yağc1, E. (2003). Öğretim teknolojileri ve materyal geliştirme. Ankara: PegemA Yayıncilik.

Ebner, M., \& Holzinger, A. (2007). Successful implementation of user-centered game based learning in higher education: An example from civil engineering. Computers \& Education, 3(49), 873-890.

Egenfeldt-Nielsen, S. (2005). Beyond Edutainment: Exploring the Educational Potential of Computer Games. http://www.itu.dk/. adresinden alınmıştır

Funk, J. B. (2003). How children experience playing video games. Proceedings of Acm International Conference, (s. 1-14).

Garris, R., Ahlers, R., \& Driskell, J. E. (2002). Games, motivation, and learning:A research and practice model. Simulation \& Gaming, 33(4), 441-467.

Gee, J. P. (2003). What video games have to teach us about learning and literacy. New York: Palgrave/St. Martin's.

Gfk. (2009, 6 15). GfK Araştırmalar. 9 10, 2010 tarihinde GfK Türkiye: http://www.gfk.com/gfkturkiye/sectors/it_and_telecom/index.tr.html adresinden alınd

Graser, M. (2009, 08 21). Videogames rock song sales. www.variety.com: http://www.variety.com/article/VR1118007573?refCatId=16 adresinden alınmıştır

Güneş, H. (2010). Geliştirilen çevrimiçi elektrogame oyununun ilköğretim 4. basamak bilişim teknolojileri dersi başarısına etkisi. Balıkesir Üniversitesi.

Hançer,A.H.(2007), Fen Eğitiminde yapılandırmacı yaklaşıma dayalı bilgisayar destekli öğrenmenin kavram yanılgılarına etkisi, C.Ü. Sosyal Bilimler Dergisi, 33(1),69-81.

Haidar, A. H. and Abraham, M. R. A. (1991), Comparison of appliedand theoretical knowledge of concepts based on the particulatenature of matter, Journal of Research in Science Teaching, 28 (10),919-938.

İpek, İ. (2001). Bilgisayarla öğretim, tasarım, geliştirme ve yöntemler. Ankara: Tıp Teknik Yayınevi.

Kar, T., Çiltaş, A. \& Işık, A., Cebirdeki Kavramlara yönelik öğrenme güçlükleri üzerine bir çalışma, Kastamonu Ĕ̈itim Dergisi, 19(3), 939-952.

Keller, J. M. (1984). The use of the ARCS model of motivation in teacher training. London: Kogan Page.

Keller, J. M., \& Suzuki, K. (1988). Application of the ARCS model to courseware design. Instructional Designs for Microcomputer Courseware, 401-434.

Kiili, K. (2005). Digital game-based learning: Towards an experiential gaming model. The Internet and Higher Education, 13-24.

Kiili, K. (2005b). Educational game design: Experiential gaming model revised. Pori: Tampere University of Technology. 
Konuksal, S. (2009, 12 15). Bölüm sonu canavart. 12 06, 2011 tarihinde sayılarla World of Warcraft: http://www.bolumsonucanavari.com/HaberlerSayilarla_World_of_Warcraft-3030.htm adresinden alınd1

Kramer, W. (2000, December). What is a Game? The Games Journal: http://www.thegamesjournal.com/articles/WhatIsaGame.shtml adresinden alınmıştır

Kula, A. (2005). Öğretimsel bilgisayar oyunlarının temel aritmetik işlem becerilerinin gelişimine etkisi. Ankara: Hacettepe Üniversitesi.

Kurnaz, M. A., \& Yiğit, N. (2010). Physics attitude scale : development , validity and reliability. Necatibey Eğitim Fakültesi Elektronik Fen ve Matematik Eğitimi Dergisi (EFMED), 4(1), 29-49.

Küçüközer, H. (2004). Yapılandırmacı öğrenme kuramına dayalı olarak geliştirilen öğretim modelinin lise 1. sınıf öğrencilerinin basit elektrik devrelerine 1lişkin kavramsal anlamalarına etkisi. Balıkesir: Balıkesir Üniversitesi.

Lee, O., Eichinger, D. C., Anderson, C. W., Berkheimer, G. D. \& Blakeslee, T. D. (1993). Changing Middle School Students' Conceptions of Matter and Molecules. Journal of Research in Science Teaching, 30 (3), 249-270.

Linderoth, J., Lantz-Andersson, A., \& Lindström, B. (2002). Electronic exaggerations and virtual worries: Mapping research of computer games relevant to the understanding of children's game play. Contemporary Issues in Early Childhood, 3(2), 226-250.

Malone, T. (1981). What makes computer games fun? Byte,. Byte, 6(12), 258-277.

Mann, B. D., Eidelson, B. M., Fukuchi, S. G., Nissman, S. A., Robertson, S., \& Jardines, L. (2002). The development of an interactive game-based tool for learning surgical. The American Journal of Surgery, 3(183), 305-308.

Maroney, K. (2001, Mayıs). My entire waking life. The Games Journal: http://www.thegamesjournal.com/articles/MyEntireWakingLife.shtml adresinden alınmıştır

Osborne, R. (1981). Children's Ideas About Electric Circuits. New Zealand Science Teacher (29), 12-19.

Pelletier, C. (2005). Studying games in school: A framework for media education. Research Association Conference.

Pillay, H. (2002). An investigation of cognitive processes engaged in by recreational computer game players: An implication for skills of the future. Journal of Research on Technology in Education(34), 336-350.

Shipstone, D., Rhöneck, C., Jung, W., C. Kärrqvist, J. D., Joshua, S., \& Licht, P. (1988). A study of students' understanding of electricity in five European countries. International Journal of Science Education, 3(10), 303-316.

Siang, A. C., \& Rao, R. K. (2003). Theories of learning: A computer game perspective. Proceedings of the IEEE Fifth International Symposium on Multimedia Software Engineering (ISMSE'03), (s. 239-244).

Süngü, E. (2010, 12 12). Call of Duty'e harcanan zaman inantlmaz! 12 06, 2011 tarihinde Chip Online Tr: http://www.chip.com.tr/konu/call-of-duty-e-harcanan-zamaninanilmaz_24274.html adresinden alındı 
Turvey, K. (2006). Towards deeper learning through creativity within online communities in primary education. Computers \& Education(46), 309-321.

Tüzün, H. (2004). Motivating learners in educational computer games. . Bloomington: Indiana University.

Uzunkavak, M. (2004). Lise ve dengi okul öğrencilerinin elektrik ve manyetizma öğreniminde karşılaştığı kavram yanılgıları. Isparta: Süleyman Demirel Üniversitesi.

Üçgül, M. (2006). The Impact Of Computer Games On Students' Motivation. Ankara: Middle East Technical University.

Ünal, M. N. (2009). Eğitsel bilgisayar oyunlarının eğlendirici ve motive edici özelliklerinin akademik başarıya ve motivasyona etkisi. Eskişehir: Anadolu Üniversitesi.

Wikipedia.

Bilgisayar

оуипи.

Wikipedia: http://tr.wikipedia.org/wiki/Bilgisayar_oyunu adresinden alınmıştır

Yağbasan, R. \& Gülçiçek, Ç. (2003). Fen öğretiminde kavram yanılgılarının karakteristiklerinin tanımlanması, Pamukkale Üniversitesi Ĕ̈itim Fakültesi Dergisi(13), 102-120.

Zin, N. A., Jaafar, A., \& Yue, W. S. (2009). Digital game-based learning (DGBL) model and development methodology for teaching history. Wseas Transactions On Computers, $8(2), 322-333$. 